\title{
Agronomic and qualitative evaluation of some olive selections derived from a breeding program
}

\author{
IBRAHIM M. S. OSMAN
}

\author{
Olive and Fruits of Semi Arid Zone Dept., Hort. Res. Inst., ARC, EGYPT
}

\begin{abstract}
A breeding olive program has been established in 1994 at Egypt by crossing between local and foreign cultivars for selection and evaluation to get new genotypes for table, oil, or dual purpose varieties. Future work is planned to evaluate the adaptation of the most promising selection to different environments.

During three successive years (2011-2013) progenies from crosses between cvs. (Leccio x Toffahi), (Coratina x Toffahi), (Toffahi x Arbiquine) and (Arbiquine x Toffahi) were evaluated. The progenies have been analyzed for some tree growth traits (shoot length, shoot thickness, number of nodes/shoot, internodes length, leaf traits (average number of leaves/shoot, leaf surface area, leaf shape), flowering-entity (flowering time, the length of inflorescence, number of total flowers/ inflorescence, number of perfect flowers/inflorescence, number of staminate flowers/ inflorescence, sex ratio, and fruit set $/ \mathrm{m}$ ), drupe traits (tree yield, fruit shape, fruit weight, seed weight, flesh weight, flesh/seed, moisture and oil content (oil percent in fresh weight and oil percent in dry weight) and rooting capability. From the obtained data, it can be concluded that some valuable selections have been resulted. Such progenies were No. 51, 62, and 63 for table olive; progenies No 36, 49, 109 and 121 for oil and No. 34, 35, 108, 110 and 111 for dual purpose. Furthermore, selected progenies were propagated and planted in three locations, to evaluate their performance in different geographical areas. Performance included i.e., tree growth, yield, fruit characteristics, oil content and oil compositions in fatty acids. There comes the necessity to study quantities and qualitative traits of olive production for the most important selections.
\end{abstract}

Key words: Olive, Progenies, Table olive, Oil Olive, Cross Breeding, Leccio, Coratina, Toffahi, Arbiquine.

\section{Introduction}

Laaribi et al., (2013) mentioned that the breeding program has been developed since 1989 (done by Dr. A. Trigui) for improving the oil content and the quality of the most important olive variety cultivated in Tunisia 'Chemlali'

Leon et al., (2013) stated that the early bearing, high yield, oil content, mechanical harvesting aptitude, expanded ripening period and oil quality are some of the main objectives of breeding programs aiming at obtaining new olive cultivars for olive oil production.

Today the market demands for cultivars with a high ecological plasticity, adaptable to new agronomical techniques, capable of producing high quality oil and for big table olive with good flavors and good technological properties. It is possible to enlarge the natural genetic variability of the olive through the cross breeding technique in which searching for interesting genotypes is aimed (Bellini et al., 2002).

In this context, any genetic improvement program by cross breeding will need strong efforts and long time to obtain next generation besides its agronomical evaluation in the field. The length of the juvenility period has been traditionally one of the main drawbacks of fruit tree breeding including olive. However, in the last years, several methodologies aimed at shortening the length of the juvenile period have been approached, thus facilitating the progress of the breeding process. (Lavee et al., 1996 and Santos-Antunes et al., 1999). This has promoted the developmental process of olive breeding programs in the main olive producing countries (Leon et al., 2006).

In olive, few breeding programs by crossing and selection in the progenies have been initiated in the past decades (Lavee, 1990; Bellini, 1992; Arsel and Cirik, 1994; Panneli et al., 2006). As a consequence, several new cultivars have been released such as Barnea (Lavee et al., 1986) Fs-17 (Fontanazza et al., 1998) Maalot (Lavee et al., 1999) "Arno, Tevere and Basento" (Bellini et al., 2000) and Askal (Lavee et al., 2003).

Comparative field trials of advanced selections from breeding programs are currently carried out in several olive producing countries (Bellini, et al., 2000; Sonnoli et al., 2003; Lavee et al., 2004 and Alfei et al., 2008). A morphological scheme of primary descriptors which proved to be suitable for discriminating cultivars has been used to determine 262 cultivated olive varieties (Rallo, 1995). The secondary characterization of many cultivars is already underway as regards some criteria such as growth, productivity and fruit parameter (Del Rio and Caballero, 1994) and resistance to abiotic factors such as calcareous soils, drought and salinity (Corderio, 1997 and Cresti et al., 1997).

Leon et al., (2004) stated that the most olive cultivars have been produced by empirical selection 
made by growers and are known to be several centuries old. The long juvenile period of olive seedlings has hampered the release of new cultivars by systematic breeding. In fact, it has been reported that it takes at least 10 years for olive seedlings to reach the adult phase and the flowering stage. The agronomic traits considered for selection are: earliness of bearing, productivity, oil production efficiency, oleic acid content, resistance to Spilocaea oleagina (Cast.) Huges and suitability to mechanical harvesting.

Biton et al., (2012) reported that the olive (Olea europaea) is one of the most important oleaginous crops of the Mediterranean basin. Increased demand for olive oil creates a need for new olive varieties to help meet the requirements of the global market. However, olive breeding has been handicapped by such varied challenges as a prolonged juvenile period, agrotechnical problems and insufficient genetic knowledge. The use of DNA markers has the potential to overcome these problems and increase the effectiveness of classical breeding programs.

Sanchez de Medina (2014) found that the growing demand for high-quality virgin olive oils (VOOs) has increased the interest in olive breeding programs. Cross-breeding is considered, within these programs, the best strategy to generate new cultivars as an attempt to improve the present cultivars.

The objective of this study was the performance of a breeding program to obtain new olive cultivars with some preferable traits such as early bearing, high productivity and high oil content, resistance to pest and diseases, vigor suitability for mechanical harvesting and high quality of olive oil.

In olive improvement project in Horticulture Research Institute Arbequina, Leccio and Coratina as an oil cvs. (foreign cvs.) were used as a mother trees. On the other hand, Toffahi (local table cv.) was used as a pollinator for these cvs.

\section{Material and Methods}

In the present work, nineteen genotypes coming from crosses between the cultivars Leccio, Toffahi, Coratina and Arbequina were selected on the basis of their agronomic characteristics in a breeding program initiated in 1994. The resulting progenies were planted during the 2000 season in the orchard of the Horticulture Research Institute at Giza, Egypt, and the evaluation was done during 2011, 2012 and 2013 seasons.

The seedlings were planted on Sept., $25^{\text {th }} 2000$ at the same orchard with planting distance $4 \times 4 \mathrm{~m}$ apart; hence seedlings have a very long juvenile phase (15-20 years) under natural conditions to begin bearing fruits only. In order to shorten the length of the juvenility period, the plants must attain sufficient height and should be grown in the erect position.
Table 1. Number of progenies derived from crosses combination.

\begin{tabular}{cc}
\hline Selections & X $\mathbf{X}$ \\
\hline 34 & Leccio x Toffahi \\
35 & Leccio x Toffahi \\
36 & Leccio x Toffahi \\
48 & Coratina x Toffahi \\
49 & Coratina x Toffahi \\
51 & Coratina x Toffahi \\
62 & Toffahi x Arbiquine \\
63 & Toffahi x Arbiquine \\
66 & Toffahi x Arbiquine \\
108 & Arbiquine x Toffahi \\
109 & Arbiquine x Toffahi \\
110 & Arbiquine x Toffahi \\
111 & Arbiquine x Toffahi \\
113 & Arbiquine x Toffahi \\
114 & Arbiquine x Toffahi \\
115 & Arbiquine x Toffahi \\
116 & Arbiquine x Toffahi \\
121 & Arbiquine x Toffahi \\
122 & Arbiquine x Toffahi \\
\hline
\end{tabular}

They should be maintained in a continuous growing phase and pruning should be avoided as far as possible with the exception of the lowest branches. Fertile substrates should be used with abundant fertilization when the seedlings reach the transition phase (i.e. from the juvenile to adult phase), which is characterized by the disappearance of the wild traits and the appearance of traits corresponding to the mature phase and the plants become potentially fertile. Standard cultural practices were followed including irrigation and fertilization.

The following characters were addressed by using the methodology for primary and secondary characterizations of olive cultivars proposed by the International Olive Council (Barranco et al., 2000). Twenty shoots were labeled on each seedling in different directions to study shoot growth, flowering, fruiting. Thirty fruits from previously tagged flowers were randomly collected at the time ripening index to avoid the influence of the ripening stage on fruit traits and rooting capability.

The descending parameters were determined as follows:-

\section{1- Tree growth parameters.}

Shoot length $(\mathrm{cm})$, shoot thickness $(\mathrm{cm})$, number of nodes/shoot, internodes length $\mathrm{cm}$ and leaf (average number of leaves/shoot, the leaf surface area $\mathrm{cm}^{2}$ and leaf shape).

- Leaf Shape: This was determined by the ratio between the length $(\mathrm{cm})(\mathrm{L})$ and width $(\mathrm{cm})(\mathrm{W})$. Elliptic, L/W < 4, Elliptic-lanceolate; L/W 4-6, lanceolate, $\mathrm{L} / \mathrm{W}>6$.

\section{2- Tree blooming parameters.}


Flowering time, the length of inflorescence $(\mathrm{cm})$, number of total flowers / inflorescence, number of perfect flowers/inflorescence, number of staminate flowers/ inflorescence and sex ratio.

3- Tree fruiting parameters: Fruit $\mathrm{set} / \mathrm{m}$ and yield $(\mathrm{kg}) /$ tree were determined.

\section{4- Fruit quality measurement.}

Fruit weight $(\mathrm{g})$, fruit shape, seed weight $(\mathrm{g})$, flesh weight $(\mathrm{g})$ and flesh/seed. Moisture and oil percent (oil content in fresh weight, oil percent in dry weight). Fruit shape was determined by the ratio between the length (L) and the width (W). Spherical: L/W < 1.25, Ovoid: L/W 1.25-1.45, Elongated: L/W $>1.45$.

- Fruit weight: very low $<2$ g, low 2-4, medium 4-6 $\mathrm{g}$, high $>6-8 \mathrm{~g}$, very high $>8 \mathrm{~g}$.

- Flesh/seed: low < 5, medium 5-7.5, high 7.5-10, very high $>10$.

- Oil percent in dry weight: Very low < 30, Low 30-40, medium 40-50, high 50-60 and very high $>60$.

5- Rooting capability: Leaf stem cutting were taken from trees on "Off" years (in mid spring or late summer) and treated with $3000 \mathrm{ppm}$ indolebutyric acid (IBA). Rooting (\%): nil 0, very low 1 - 20, low 20-40, medium 40-60, high 60-80, very high 80-100.

The above categories have been established according to the international olive council (Barranco et al., 2000).

\section{Results and Discussion}

\section{1-Tree growth parameters. a- Shoot length.}

Fig., 1 indicates that progenies No. 63 derived from cvs. (Toffahi $x$ Arbiquine) had the longest shoots than parental cultivars. As well as progeny No 122, derived from cvs. (Arbiquine $\mathrm{x}$ Toffahi) and progeny No. 63 (Toffahi x Arbiquine) gave also the longest shoots than parental cultivars, while the progeny No 48 derived from cvs. (Coratina $\mathrm{x}$ Toffahi) produced the lowest shoot length than the parental cultivars.

\section{b- Shoot thickness.}

Fig., 2 shows that the shoots of progenies No. 113 (Arbiquine $\mathrm{x}$ Toffahi) were the thicker as well as the shoots of Arbiquine and Toffahi. On the other side, shoots of progeny No. 62 (Toffahi x Arbiquine) were the thinnest ones. The standard error is ranging from 0.06 to 0.37 .

\section{c- Number of nodes/shoot. \\ It is clear from Fig., 3 illustrates that the progenies No. 63 derived from (Toffahi $x$ Arbiquine), No 122 derived from (Arbiquine $\mathrm{x}$ Toffahi) and Toffahi gave the highest number of}

nodes and higher value than No. 48 derived from (Coratina x Toffahi) and cv. Coratina as compared with all other tested progenies.

\section{d- Internodes length.}

It is obvious from Fig., 4 that the progenies No. 49 and 111 (Coratina $\mathrm{x}$ Toffahi) and (Arbiquine $\mathrm{x}$ Toffahi) as well as cvs. Coratina and Leccio gave the longest internodes than cvs. Toffahi and Arbiquine, while the shortest internodes were found in progenies No. 62 and 113 (Toffahi x Arbiquine) and (Arbiquine $\mathrm{x}$ Toffahi). The standard error is ranging from 0.02 to 0.10 .

\section{e- Number of leaves/shoot.}

It is obvious from Fig., 5 that the progenies No. 63 (Toffahi $x$ Arbiquine) and No. 122 (Arbiquine $\mathrm{x}$ Toffahi) and cv. Toffahi produced the highest number of leaves/shoot, while the lowest value was obtained by progenies No. 111 and 48 (Arbiquine $\mathrm{x}$ Toffahi), (Coratina $\mathrm{x}$ Toffahi) and $\mathrm{cv}$. Coratina.

\section{f- Leaf surface area.}

Leaf surface area varied among the tested progenies as shown in Fig., 6. The progeny derived from (Coratina $\mathrm{x}$ Toffahi) and cv. Toffahi gave the largest leaves than cvs., (Leccio and Arbiquine) whereas the narrowest leaves were obtained in the cv. Arbiquine. The rest tested progenies gave intermediate values in this respect.

\section{g- Leaf shape.}

Data in Fig., 7 demonstrate that the progenies No 48 and 63 derived from (Coratina $\mathrm{x}$ Toffahi) and (Toffahi x Arbiquine), as well as, progenies No. 116, 121 and 122 derived from (Arbiquine $\mathrm{x}$ Toffahi) took Elliptic lanceolate date leaf shape like Leccio cv.

Differences in growth characteristics among olive selections are in close conformity with the findings previously reported by many researchers (Bellini et al., 1990 and 2000, Rallo, 1995, Trigui 1996, Damijela, et al 2008, Pritsa et al., 2003, Bartolini et al., 2006, and Bellini et al., 2008 and Medina et al., 2012).

2- Tree blooming parameters. a- Flowering time (start, end and duration). Table, 2 indicates that the progenies derived from cvs. (Leccio x Toffahi); (Coratina x Toffahi); (Toffahi $x$ Arbiquine) and (Arbiquine $\mathrm{x}$ Toffahi) began flowering $9 / 3$ to $18 / 3 ; 12 / 3$ to $17 / 3 ; 7 / 3$ to $16 / 3$ and $6 / 3$ to $17 / 3$ began flowering, respectively.

\section{b- Number of total flowers/inflorescence.}

It is clear from Fig., 8 that mean number of flowers/ inflorescence was 21.49. Progenies No. 108 and 115 (Arbiquine x Toffahi), No 62 (Toffahi x Arbiquine) and cv. Arbiquine produced the highest number of flowers/ inflorescence. On the other hand, 
progenies No. 116 and 35 (Arbiquine x Toffahi) and (Leccio x Toffahi) had the lowest value and the rest progenies gave an intermediate values.

\section{c- Number of perfect flowers/ inflorescence.}

Data in Fig. 9 indicate marked variations among tested progenies. The highest values of perfect flowers were in progenies No. 109 and 108 (Arbiquine x Toffahi), No 62 (Toffahi x Arbiquine) and $\mathrm{cv}$. Arbiquine. On the other side, the progeny No. 48 (Coratina $\mathrm{x}$ Toffahi) scored the lowest value and the rest progenies gave an intermediate values.

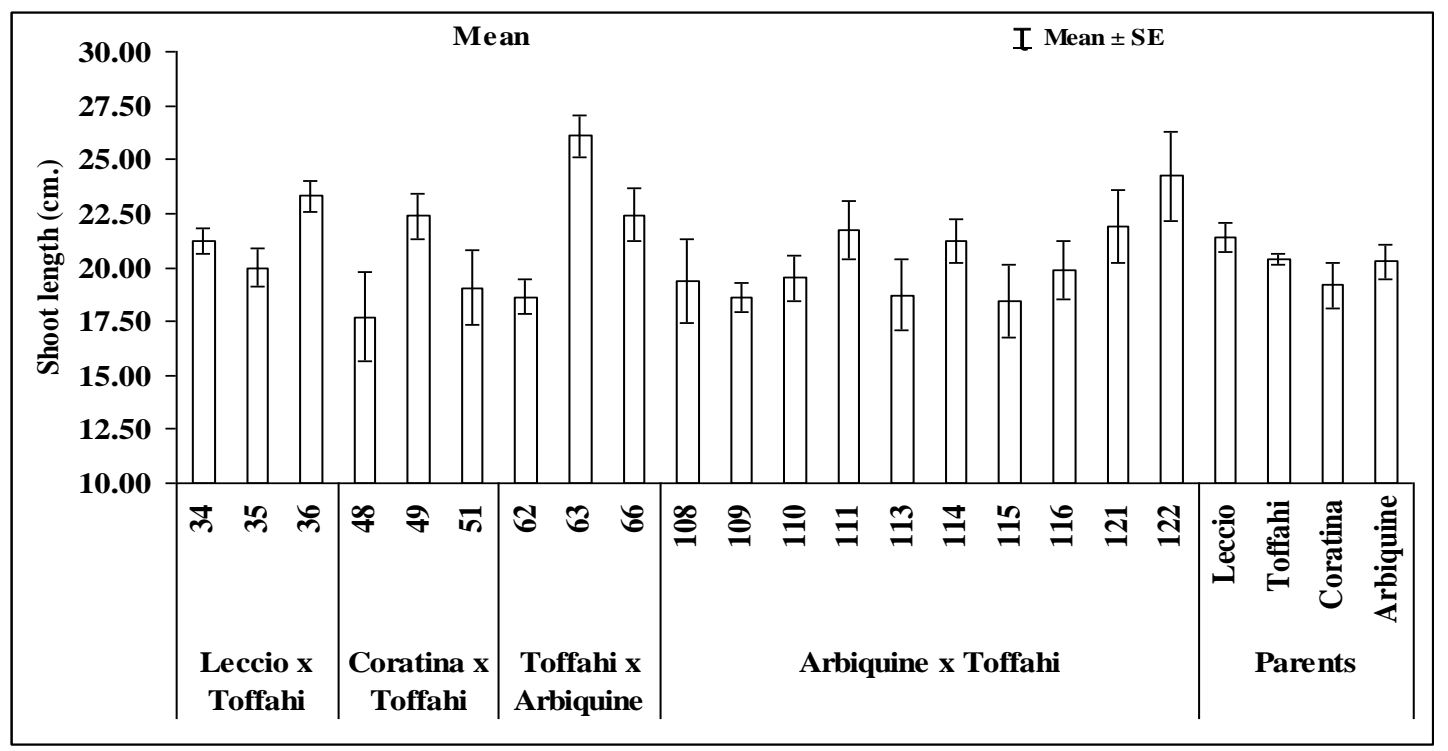

Fig., 1. Mean and standard error during three seasons for shoot length $(\mathrm{cm}$.$) of the olive progenies.$

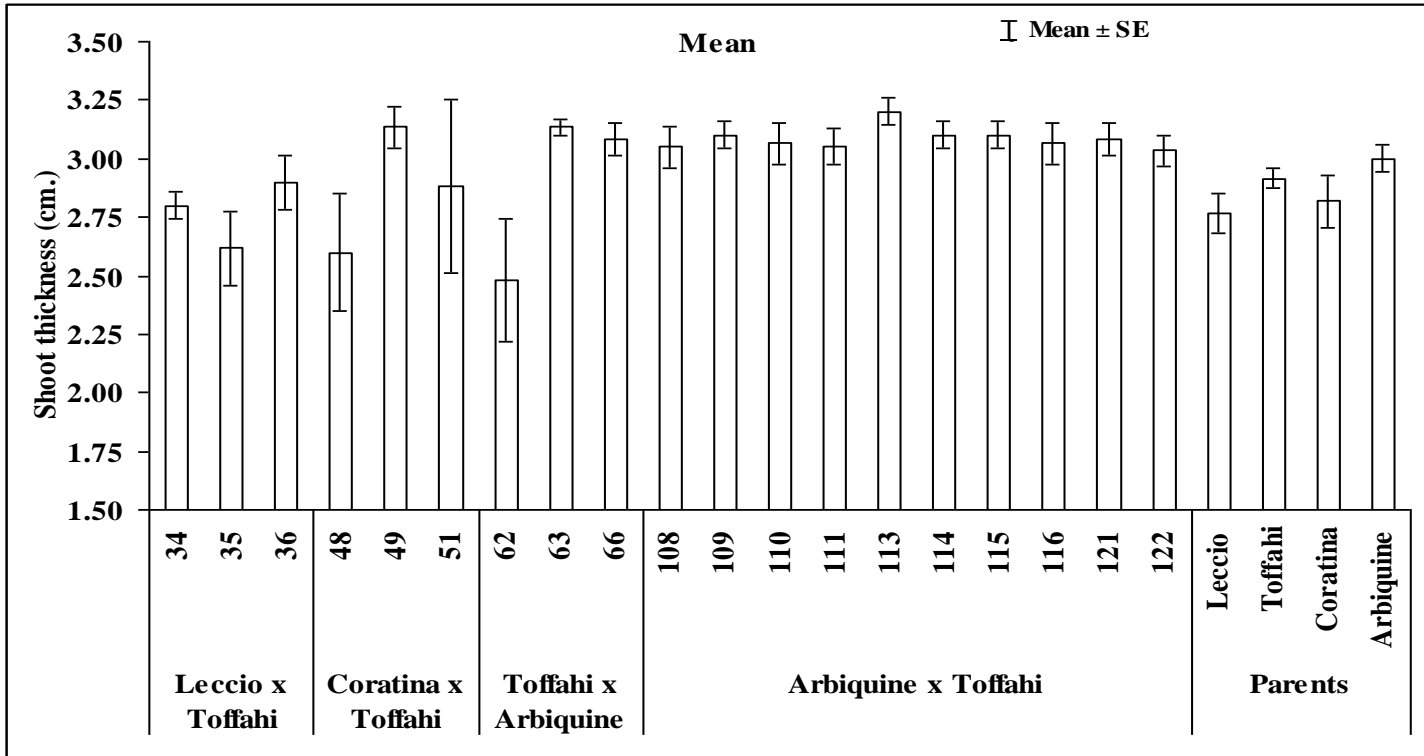

Fig., 2. Mean and standard error during three seasons for shoot thickness (cm.) of the olive progenies. 


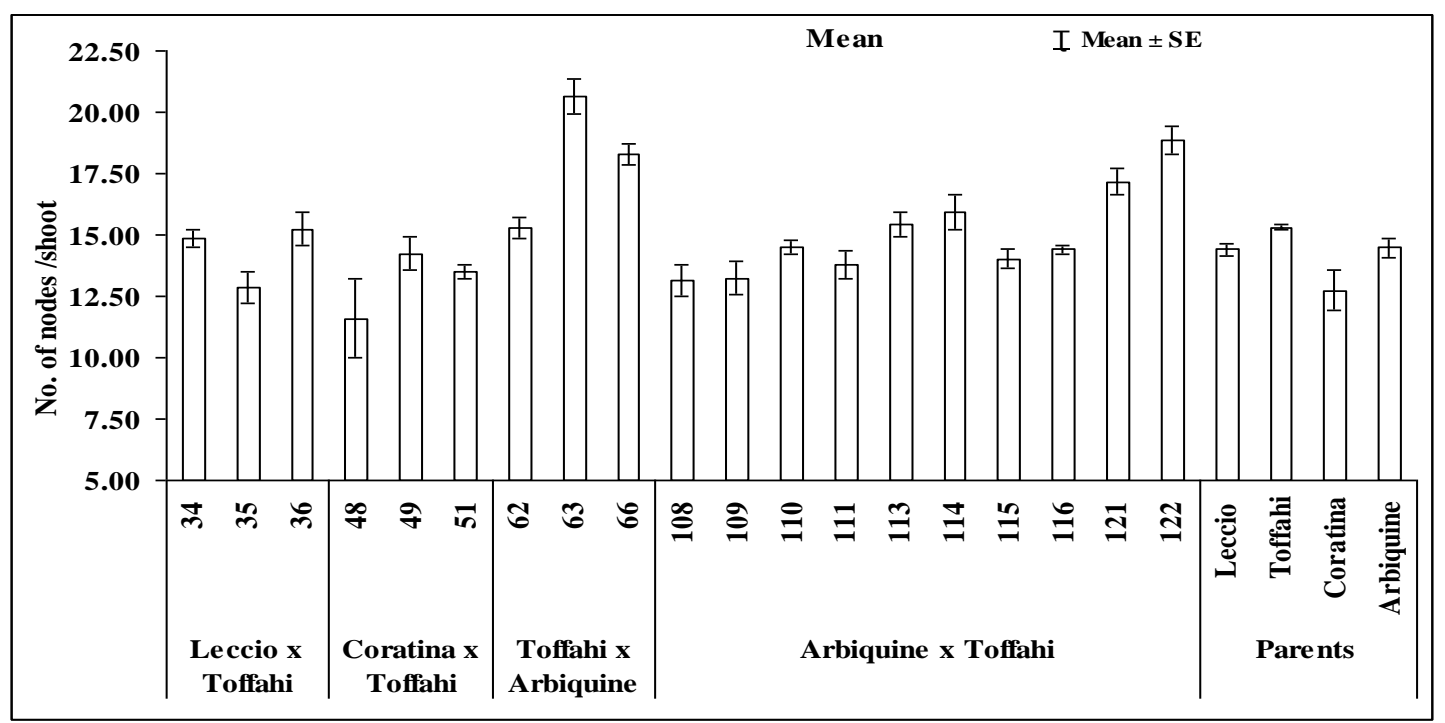

Fig., 3. Mean and standard error during three seasons for no. of nodes /shoot of the olive progenies.

Table, 2. Time of flowering.

\begin{tabular}{|c|c|c|c|}
\hline Progeny No & Start of blooming & End of blooming & Blooming duration \\
\hline 34 & $9 / 3$ & $31 / 3$ & 22 \\
\hline 35 & $8 / 3$ & $30 / 3$ & 20 \\
\hline 36 & $18 / 3$ & $7 / 4$ & 22 \\
\hline 48 & $15 / 3$ & $6 / 4$ & 19 \\
\hline 49 & $17 / 3$ & $5 / 4$ & 22 \\
\hline 51 & $10 / 3$ & $1 / 4$ & 25 \\
\hline 62 & $16 / 3$ & $4 / 4$ & 21 \\
\hline 63 & $7 / 3$ & $28 / 3$ & 19 \\
\hline 66 & $11 / 3$ & $30 / 3$ & 22 \\
\hline 108 & $7 / 3$ & $29 / 3$ & 20 \\
\hline 109 & $14 / 3$ & $3 / 4$ & 23 \\
\hline 110 & $8 / 3$ & $31 / 3$ & 21 \\
\hline 111 & $10 / 3$ & $30 / 3$ & 22 \\
\hline 113 & $6 / 3$ & $28 / 3$ & 22 \\
\hline 114 & $15 / 3$ & $4 / 4$ & 20 \\
\hline 115 & $7 / 3$ & $29 / 3$ & 20 \\
\hline 116 & $11 / 3$ & $31 / 3$ & 21 \\
\hline 121 & $12 / 3$ & $1 / 4$ & 24 \\
\hline 122 & $17 / 3$ & $7 / 4$ & 22 \\
\hline Leccio & $22 / 3$ & $15 / 4$ & 21 \\
\hline Toffahi & $5 / 3$ & $27 / 3$ & $10 / 4$ \\
\hline Coratina & $18 / 3$ & $10 / 4$ & 2 \\
\hline Arbiquine & $20 / 3$ & & \\
\hline & & & \\
\hline
\end{tabular}




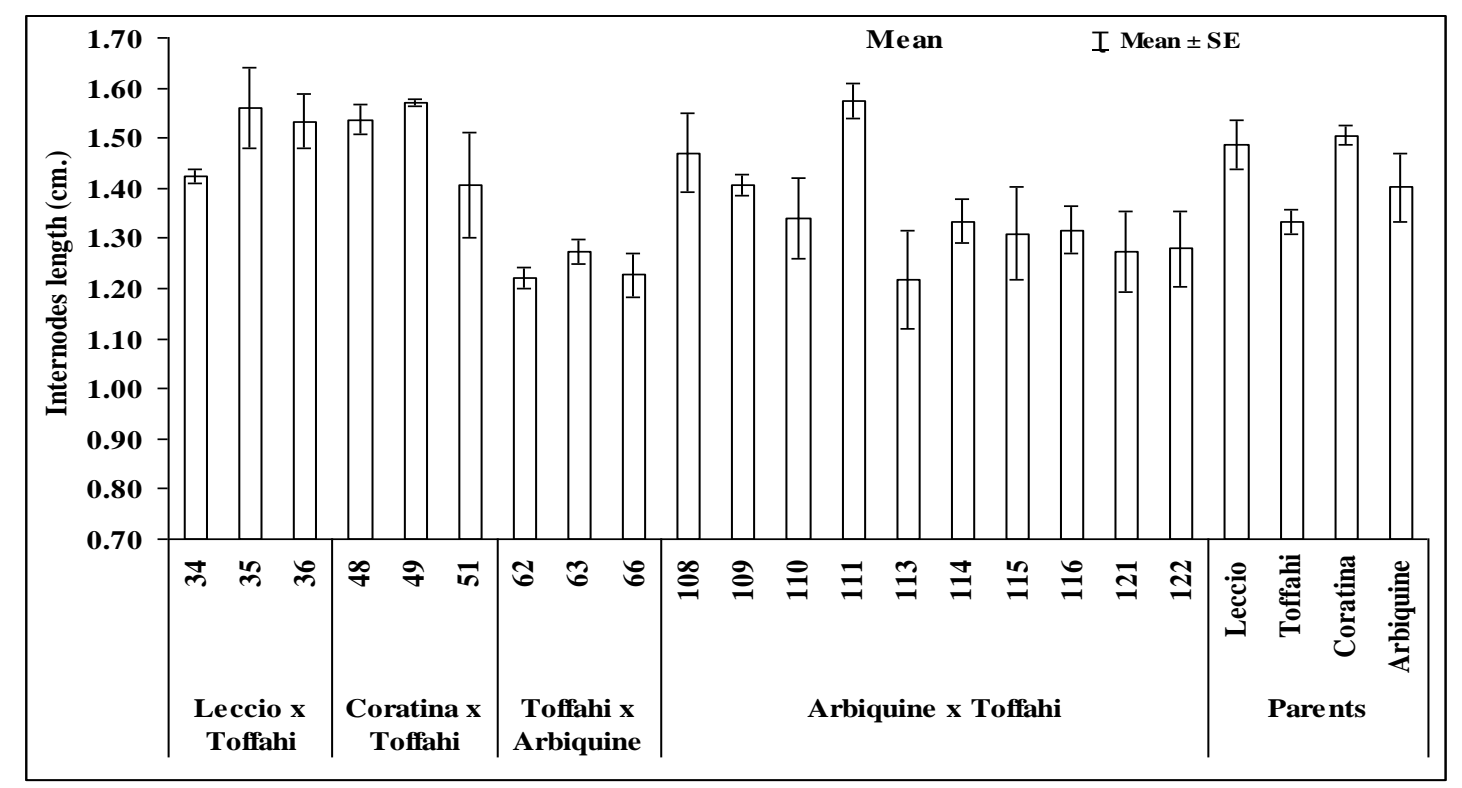

Fig., 4. Mean and standard error during three seasons for internodes length $(\mathrm{cm}$.) of the olive progenies.

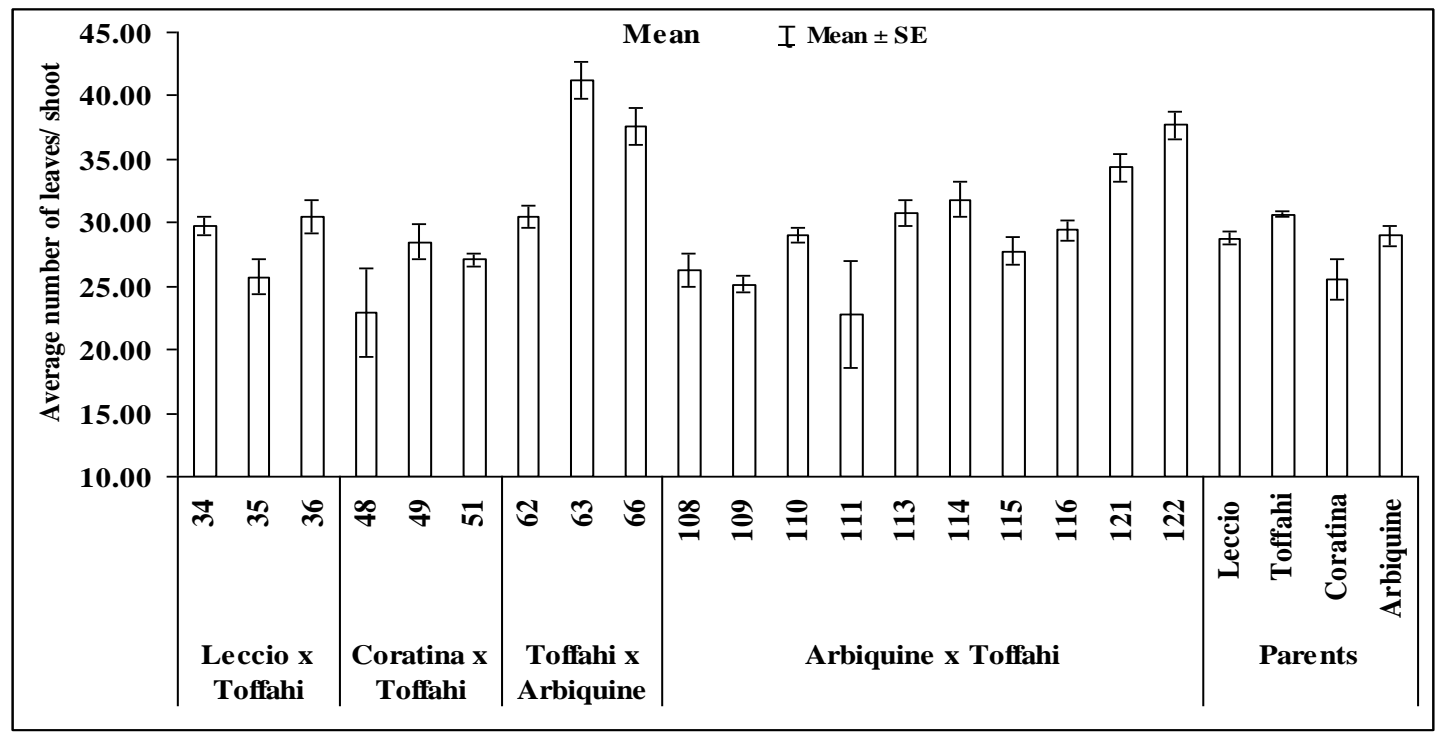

Fig., 5. Mean and standard error during three seasons for average number of leaves/ shoot of the olive progenies.

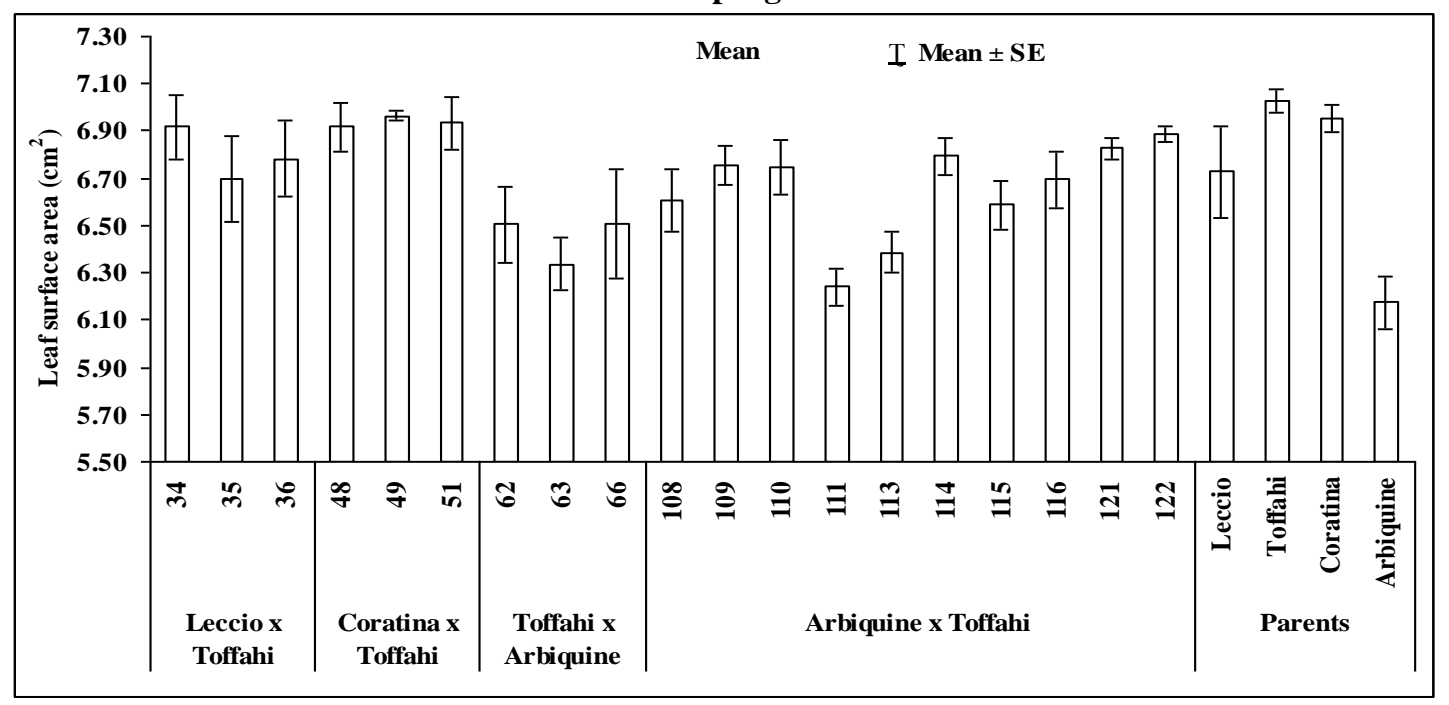

Fig., 6. Mean and standard error during three seasons for leaf surface area $\left(\mathrm{cm}^{2}\right)$ of the olive progenies. 


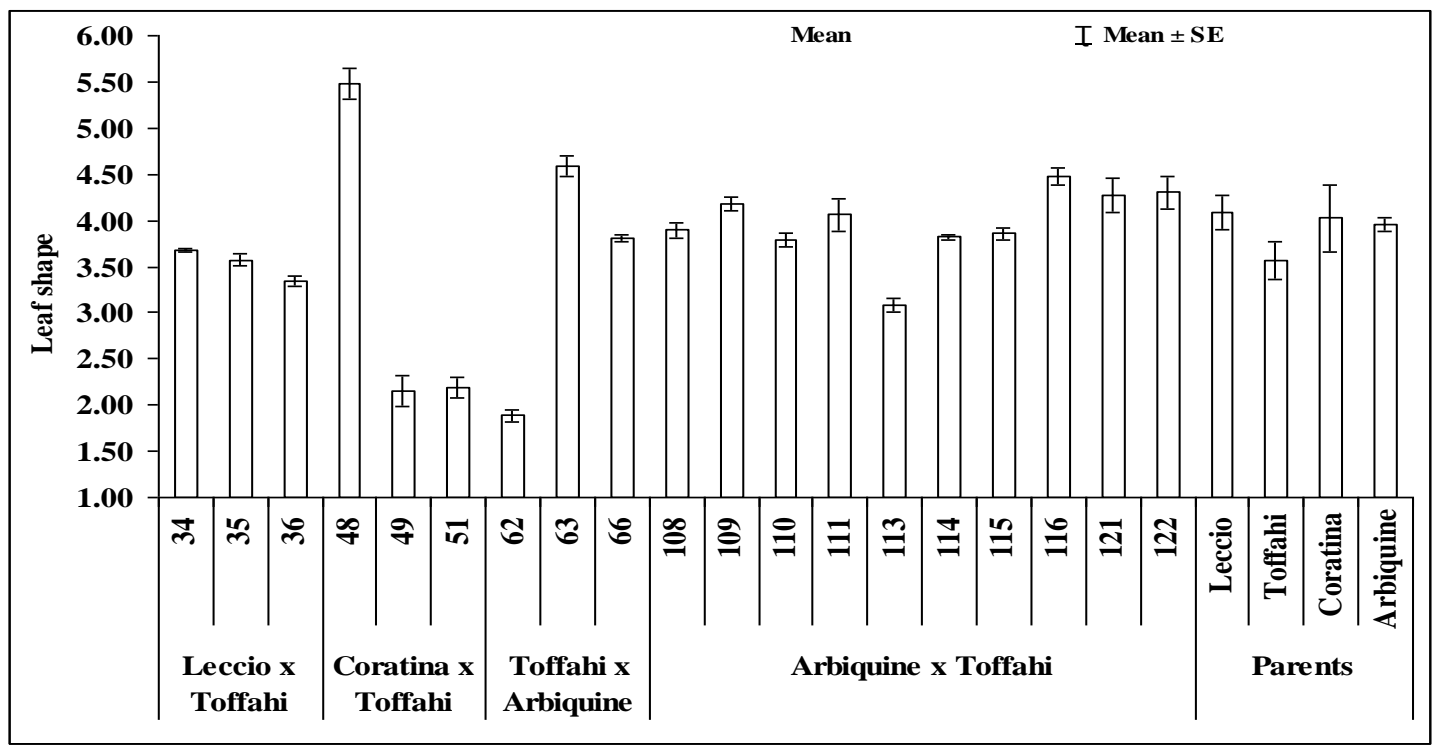

Fig., 7. Mean and standard error during three seasons for leaf shape of the olive progenies.

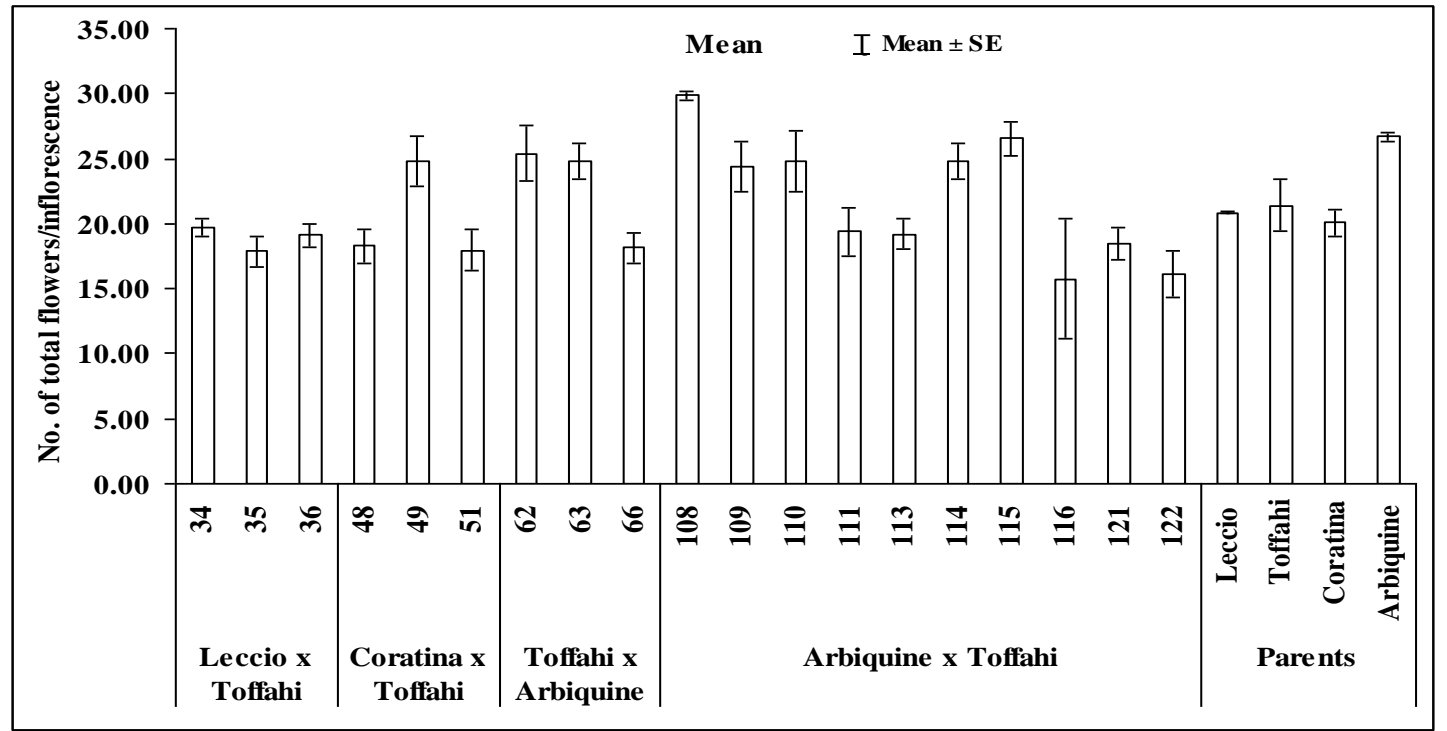

Fig., 8. Mean and standard error during three seasons for No. of total flowers/inflorescence of the olive progenies.

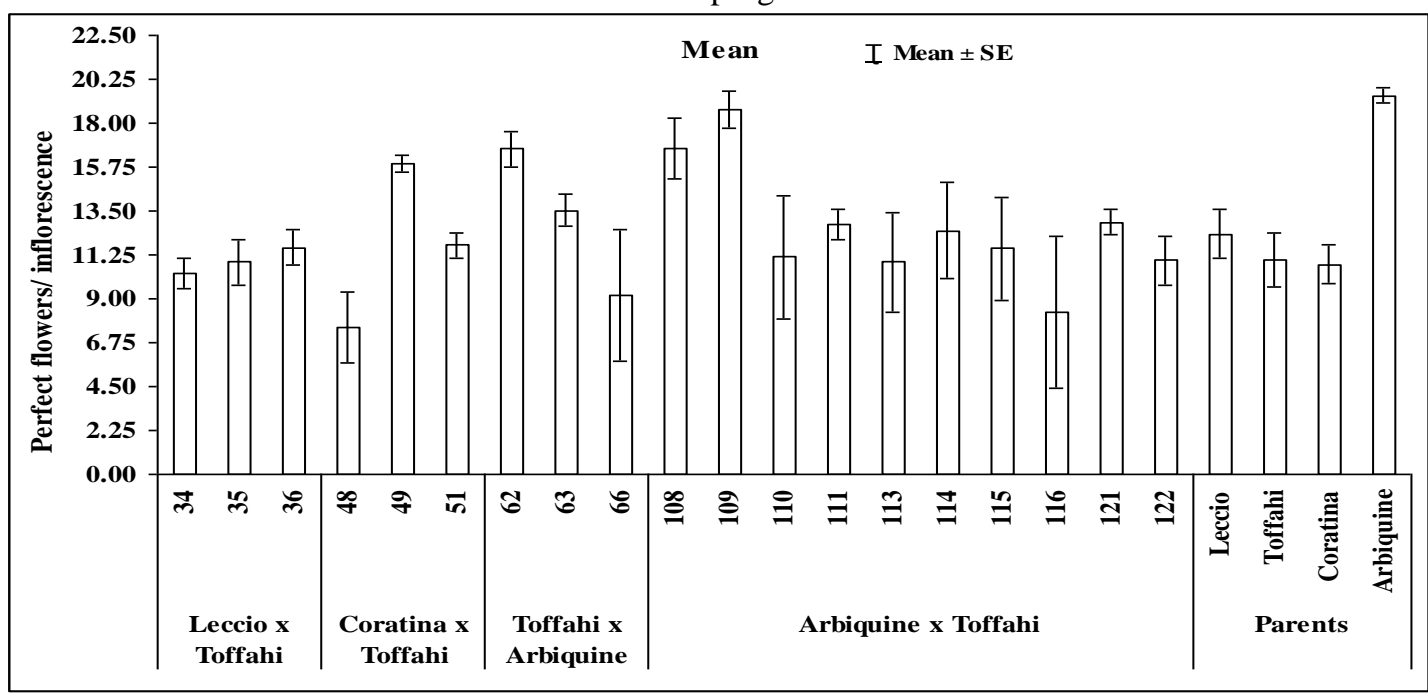

Fig., 9. Mean and standard error during three seasons for perfect flowers/ inflorescence of the olive progenies. d- Number of male flowers/ inflorescence. 
It is noticed from Fig., 10 that progenies No. 110 and 108 (Arbiquine $\mathrm{x}$ Toffahi) gave the highest value, while progenies No 122, 121 and 109 (Arbiquine $\mathrm{x}$ Toffahi) gave the lowest values than cvs. Arbiquine and Leccio and the rest progenies gave intermediate numbers.

\section{e- Inflorescence length.}

According to Fig., 11 the progenies No. 110, 108 and 122 (Arbiquine $\mathrm{x}$ Toffahi) and cv. Arbiquine gave the highest values, while the progenies No. 66 (Toffahi $\mathrm{x}$ Arbiquine) and cv. Coratina scored the lowest ones.

Differences in growth characteristics among the tested olive progenies are in close conformity with the findings previously reported by Bellini et al., (2000), Ferri et al., (2006), Bellini et al., (2008) and Hechmi et al., (2012).

\section{f - Sex ratio.}

Fig., 12 illustrates that progenies No. 109, 121 and 111 (Arbiquine $\mathrm{x}$ Toffahi) gave the highest value than the cv. Toffahi, while progeny No. 48 (Coratina $\mathrm{x}$ Toffahi) had the lowest value and the rest progenies gave an intermediate values.

\section{3- Tree fruiting.}

\section{a- Fruit set/m.}

It is obvious from Fig., 13 that the highest value of fruit set was reported by progeny No. 48 and 113 (Coratina $\mathrm{x}$ Toffahi), (Arbiquine $\mathrm{x}$ Toffahi) and cv. Toffahi than cv. Coratina. Conversely, the lowest values in this respect were obtained by progeny No. 49 (Coratina x Toffahi).

\section{b- Yield (kg)/tree:}

Data reported in Fig., 14 showed that progenies No. 51, 49 and 48 (Coratina $x$ Toffahi) were the most promising progenies in producing the highest yield, that ranged between 28.60 to $28.00 \mathrm{~kg}$ /tree than the parents cvs. Toffahi \& Coratina followed by progenies No. 35, (Leccio x Toffahi); also rather than the parents cvs. Toffahi and Leccio following No. 122 (Arbiquine x Toffahi). The least total yield/tree was produced by progeny No. 116 (Arbiquine x Toffahi). Progenies No. 51, 49 and 48 (Coratina $\mathrm{x}$ Toffahi) gave constant yield during the three years. The standard error is ranging for those progenies are ranging from 3.76 to 1.57 ; also the progeny No. 35 (Leccio x Toffahi) gave constant productivity. The standard error is 1.45 .

Similar results in the Olive Germoplasm Bank of Cordoba showed mean accumulated fruit yield in the first three years of bearing from 2 to $52 \mathrm{~kg}$ per tree among cultivars (Leon et al., 2006 and Medina $e t$ al., 2012).

4- Fruit quality.

\section{a- Fruit shape.}

Data in Fig., 15 showed that progeny No 35, resulted from (Leccio $\mathrm{x}$ Toffahi), take Ovoid fruit shape like cv. Toffahi as well as progenies No 63, 66, 115 and 122 resulted also from (Toffahi x Arbiquine) and (Arbiquine $\mathrm{x}$ Toffahi) took the Ovoid also fruit shape like cv. Toffahi, also progeny No 34 resulted from (Leccio x Toffahi) took Spherical fruit shape like cv. Leccio and the last group progeny No 48 derived from (Coratina $\mathrm{x}$ Toffahi) take Elongated fruit shape like Coratina cv.

\section{b- Fruit weight, seed weight, flesh weight and} flesh/seed.

Data presented in Figs., 16, 17, 18 and 19 show that progenies derived from (Leccio x Toffahi) No. 34, 36 and 35 produced the heaviest fruits weight. It scored 6.68, 6.60 and $6.41 \mathrm{gm}$, followed progeny (Arbiquine x Toffahi) No. 121 (5.87) more than the fruits for cvs. (Leccio and Arbiquine), while progenies derived from (Arbiquine $\mathrm{x}$ Toffahi) No. 116 and 114 gave the lightest fruit weight; it was ranging from 2.59 and $2.74 \mathrm{gm}$.

Also seed weight and flesh weight took analogous trend to that of fruit weight. As for determination of flesh seed ratio, the resulted progenies showed a large variation in this parameter, ranging from 3.83 to 8.16 . The highest value of $\mathrm{F} / \mathrm{S}$ ratio was noticed with progeny No. 51 (Coratina $\mathrm{x}$ Toffahi) more than cvs. Parents, followed by progenies No. 63 and 36 (Toffahi x Arbiquine) and (Leccio $\mathrm{x}$ Toffahi) also more than cvs. parents. The $\mathrm{F} / \mathrm{S}$ ratio is extremely important because it is an indication for oil content.

Parents in fruit weight, seed weight, flesh weight and flesh/seed parameters the highest value was scored by Toffahi and Coratina. On the contrary, the least resulted values were recorded by Leccio and Arbiquine.

\section{c- Moisture content.}

Moisture content is a major factor for olives as it generally contributes to more that $50 \%$ of the fruit weight. Data in Fig., 20 show that the mean moisture was generally high, around $65.57 \%$. The progenies derived from (Leccio x Toffahi) showed that the moisture was ranging from 63.73. to 64.41\%; (Coratina $\mathrm{x}$ Toffahi) clear that the moisture was ranging from 64.35 to 65.42 as well as the progenies derived from (Toffahi $x$ Arbiquine) showed that the moisture content was ranging between 70.24 to 70.71 and the last group progenies derived from (Arbiquine $\mathrm{x}$ Toffahi) showed that the moisture content was ranging between 63.45 to 66.85 .

Moisture content of the fruit is important to oil quality for a number of reasons, if the fruit moisture level drops to a point where desiccation occurs, cell break down can follow leading to increase of free fatty acids and therefore lower oil quality (Ayton, et al., 2001 and Medina et al., 2012). 


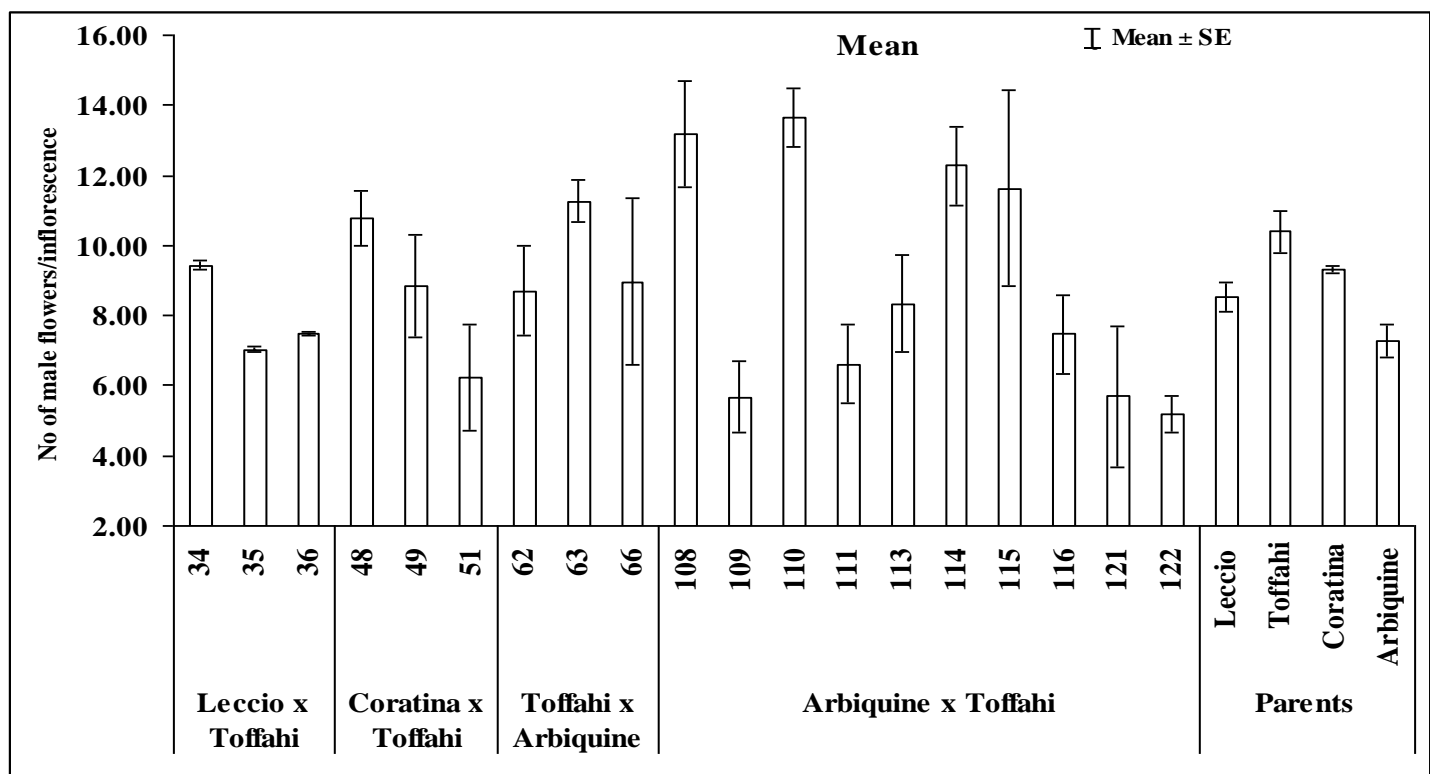

Fig., 10. Mean and standard error during three seasons for No of male flowers/inflorescence of the olive progenies.

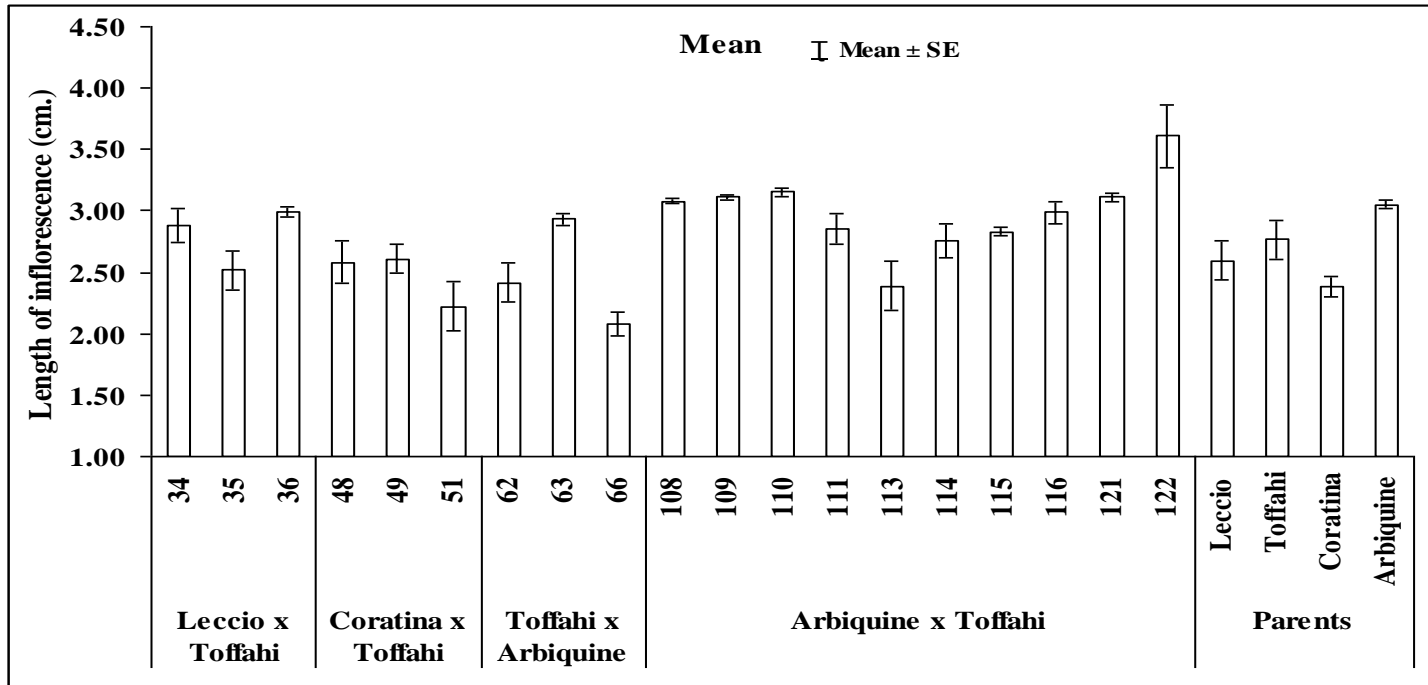

Fig., 11. Mean and standard error during three seasons for length of inflorescence $(\mathrm{cm}$.) of the olive progenies.

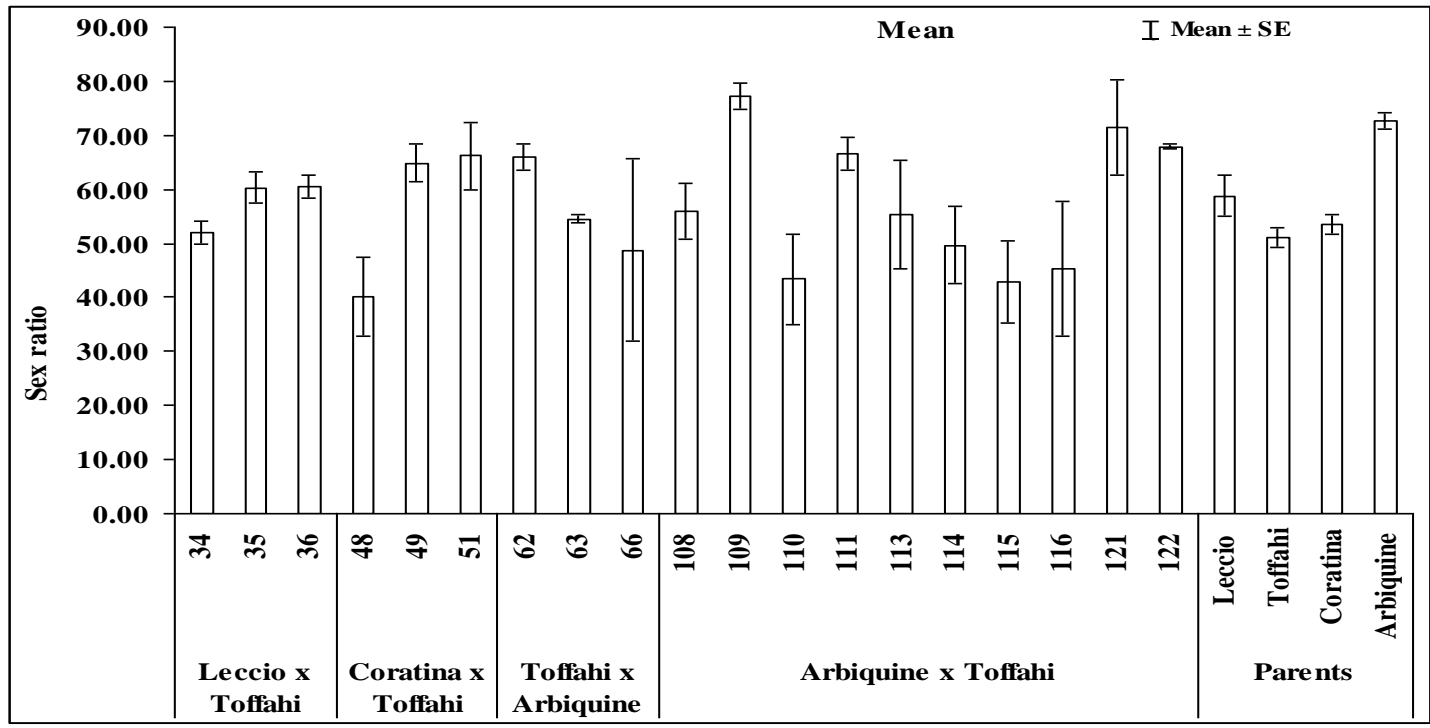

Fig., 12. Mean and standard error during three seasons for sex ratio of the olive progenies. 


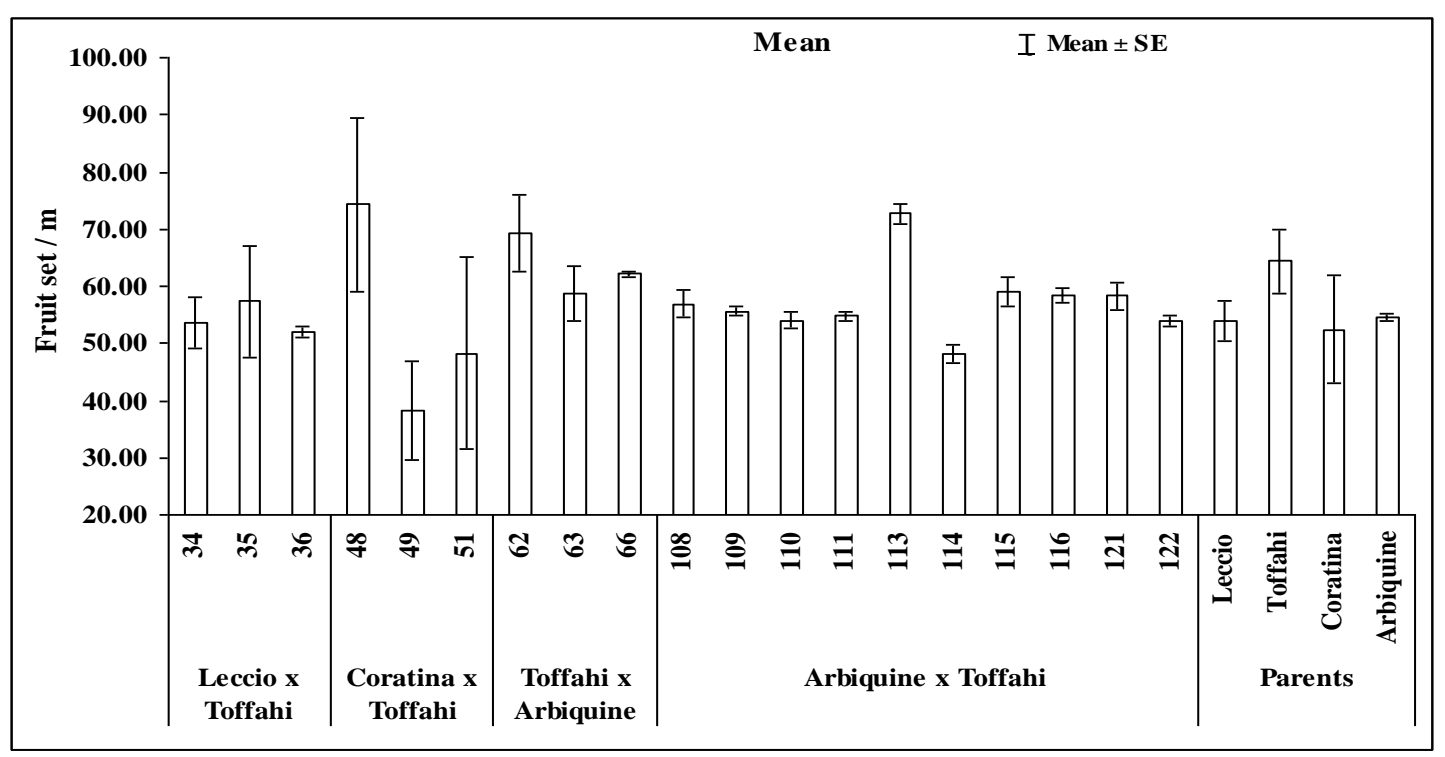

Fig., 13. Mean and standard error during three seasons for fruit set / $\mathrm{m}$ of the olive progenies

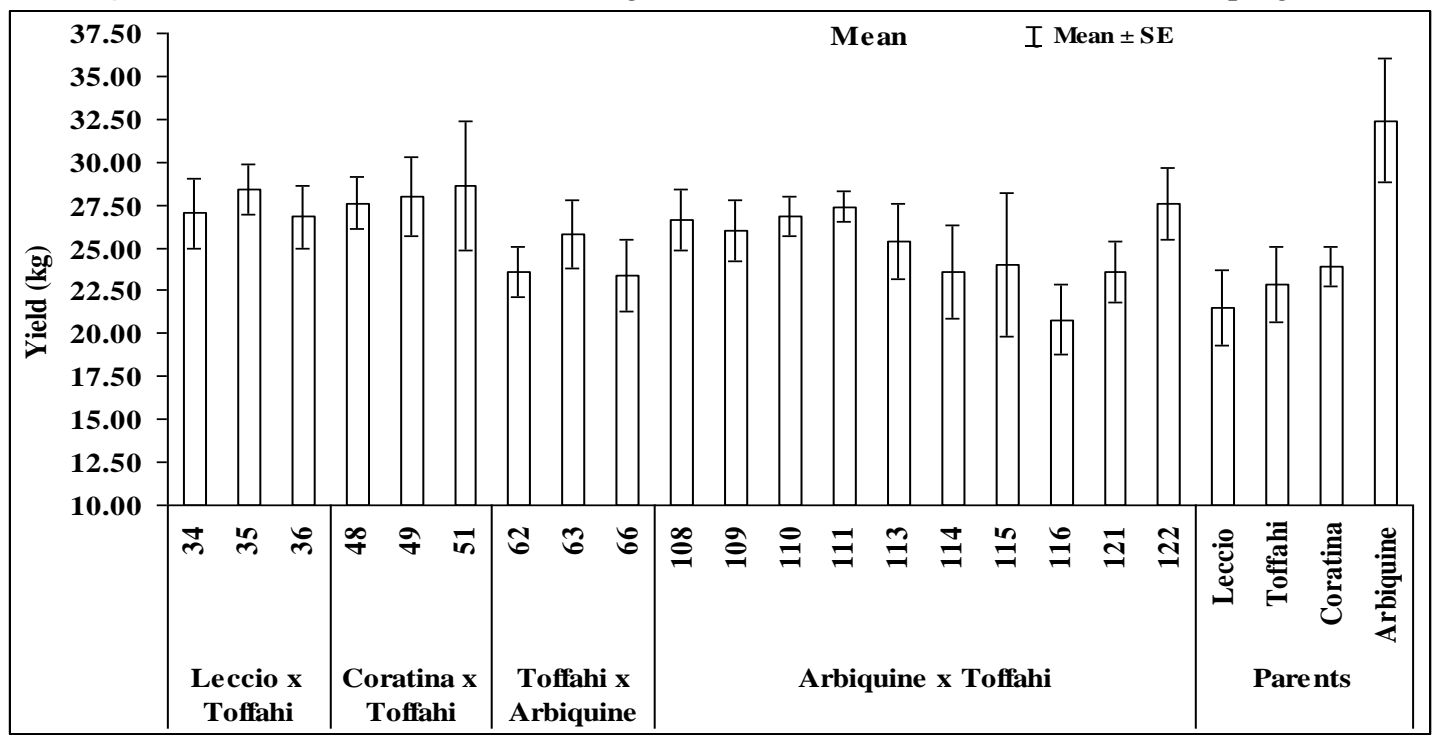

Fig., 14. Mean and standard error during three seasons for yield $(\mathrm{kg}) /$ tree of the olive progenies

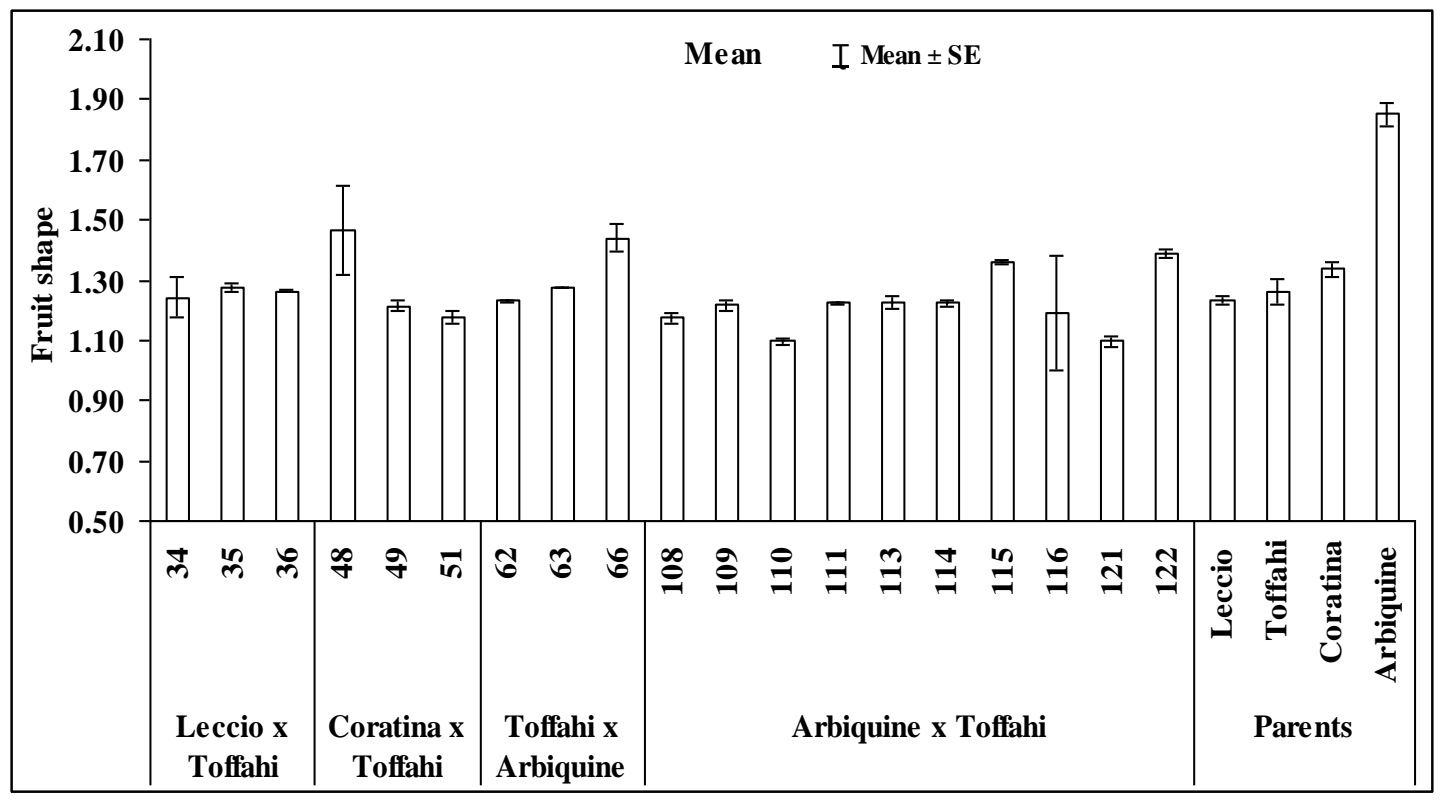

Fig., 15. Mean and standard error during three seasons for fruit shape of the olive progenies 


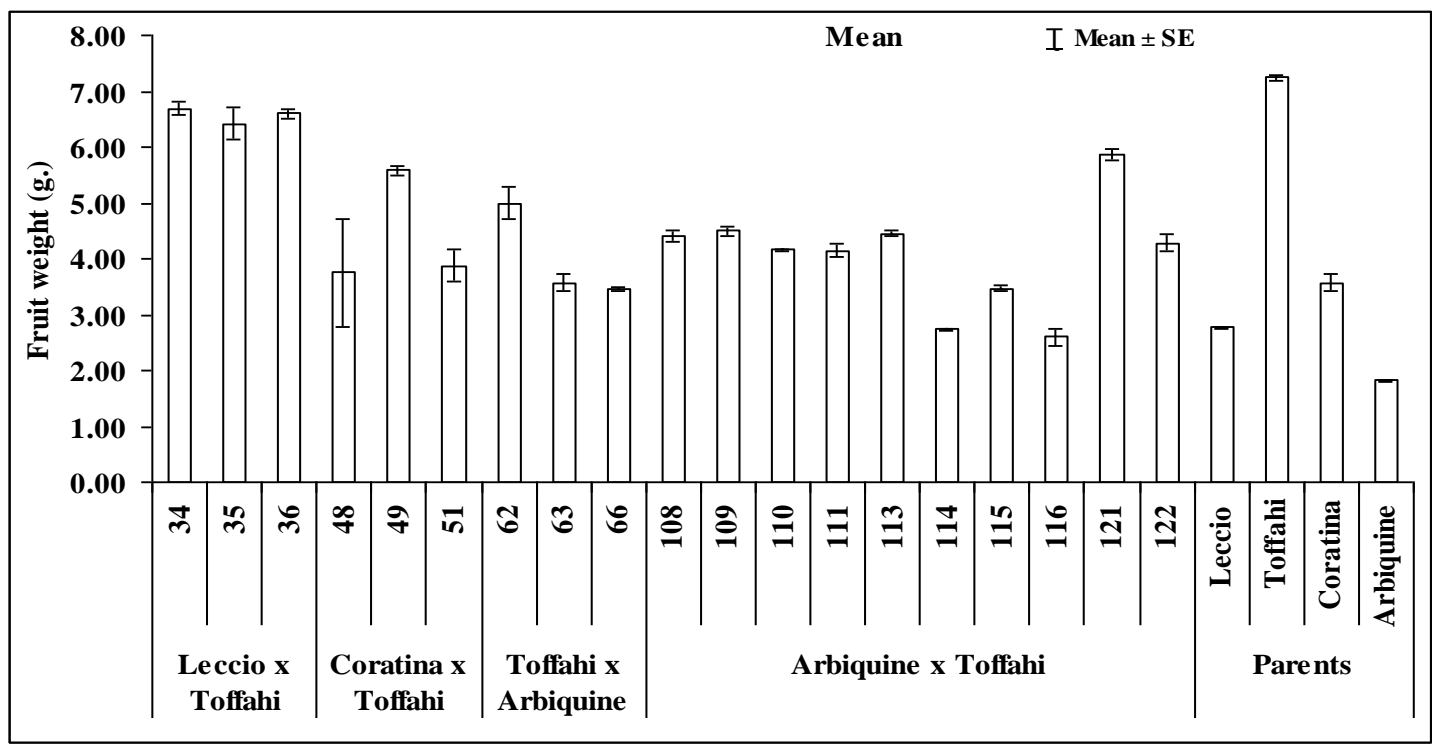

Fig., 16. Mean and standard error during three seasons for fruit weight (g.) of the olive progenies

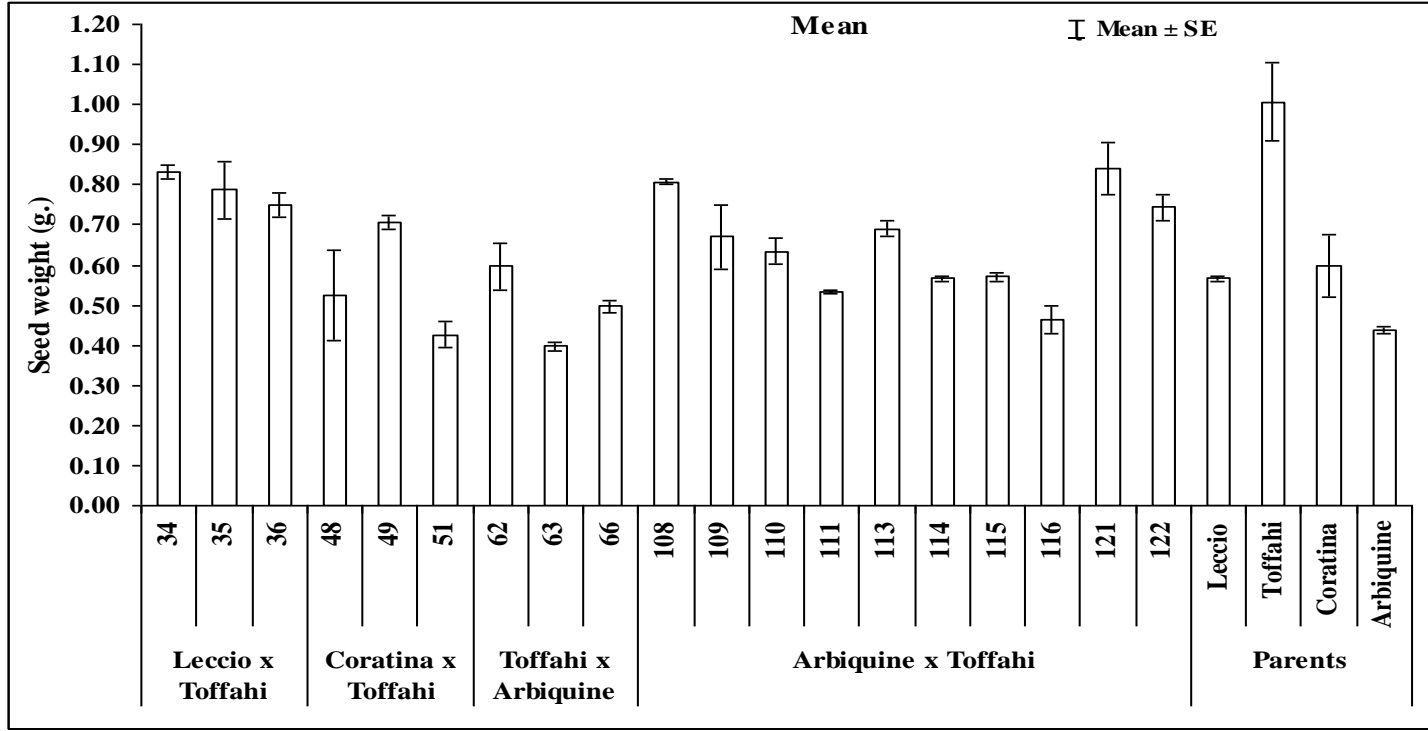

Fig., 17. Mean and standard error during three seasons for seed weight (g.) of the olive progenies

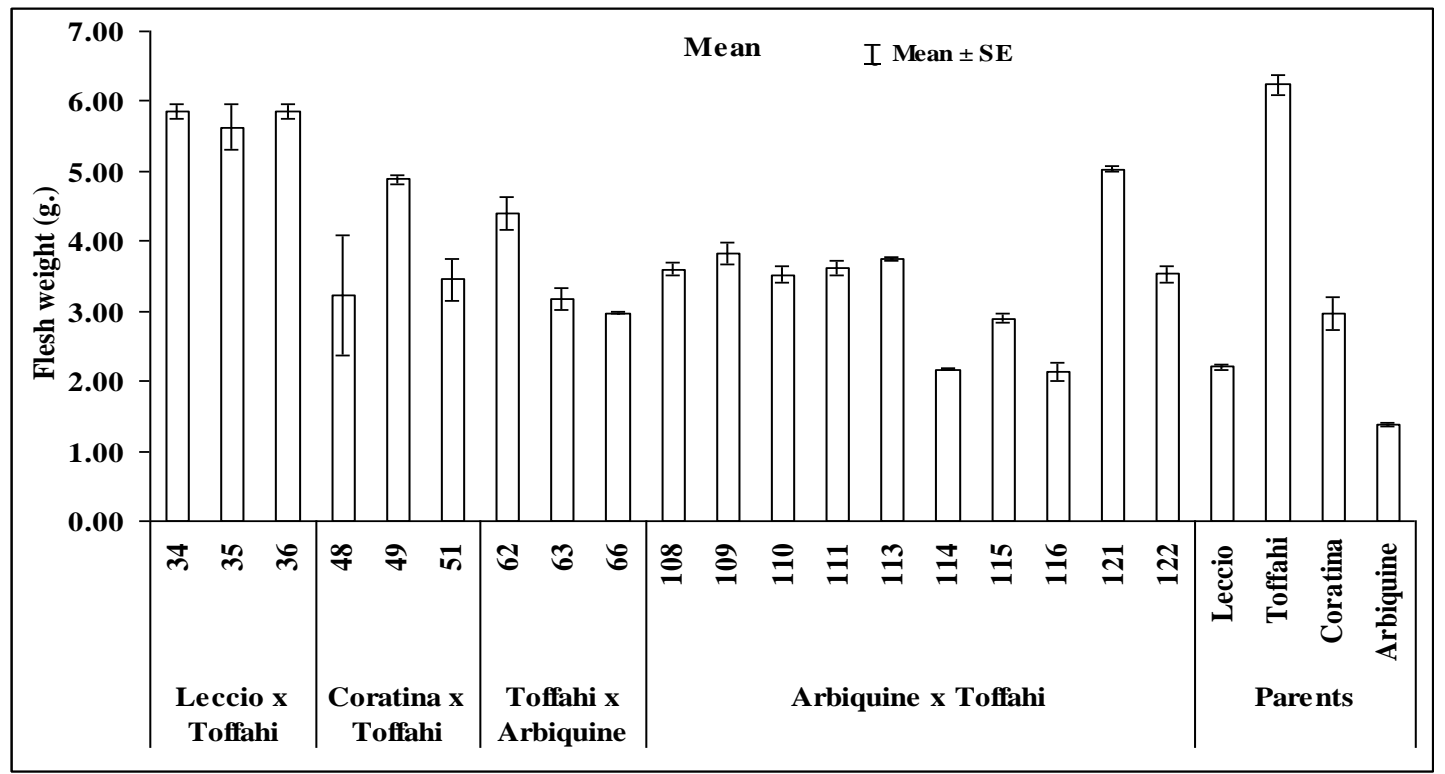

Fig., 18. Mean and standard error during three seasons for flesh weight (g.) of the olive progenies 


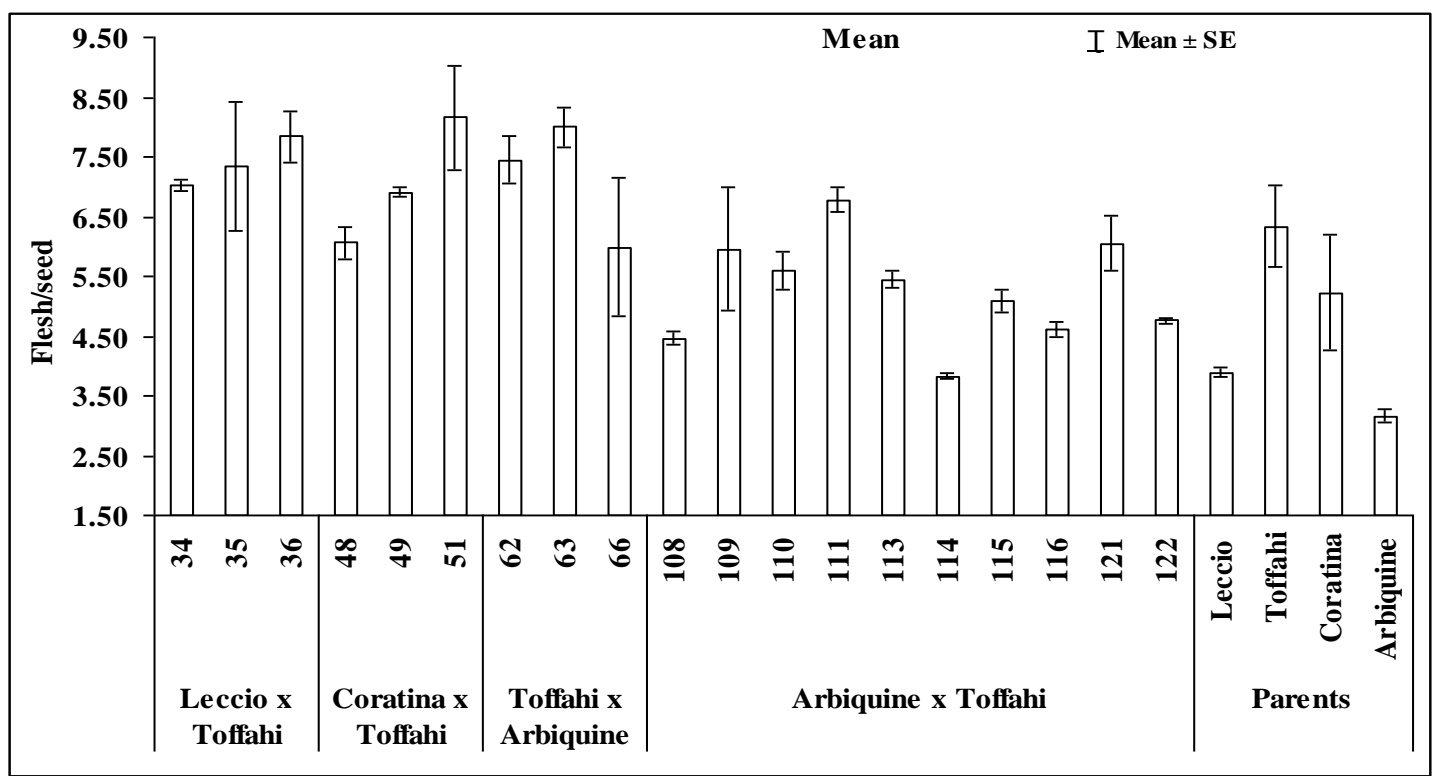

Fig., 19. Mean and standard error during three seasons for flesh/seed of the olive progenies.

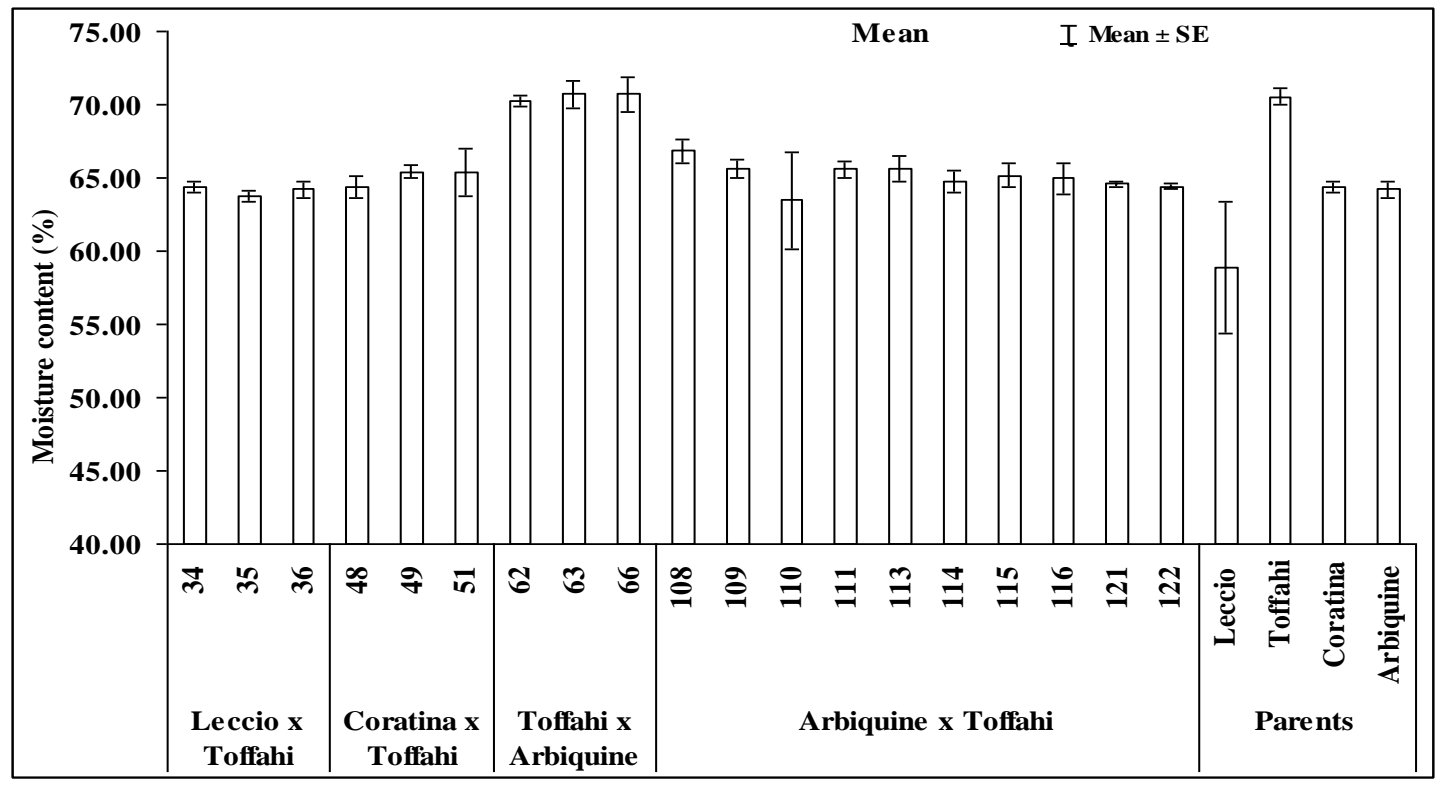

Fig., 20. Mean and standard error during three seasons for moisture content (\%) of the olive progenies.

\section{d- Oil content in fresh weight.}

Olive fruit yield and oil content are the major contributors for profitability of olive growers the average oil \% extracted was determined and is illustrated in Fig., 21 Oil content is expressed as a percentage of the fresh weight of olives.

The progenies derived from (Leccio $\mathrm{x}$ Toffahi) showed that oil content was ranging from 18.64 to $19.11 \%$. On the other side, progenies derived from (Coratina $\mathrm{x}$ Toffahi) showed that oil content was ranging from 18.28 to $18.72 \%$. Besides, (Toffahi $x$ Arbiquine) noticed that oil content was ranged from 11.58 to $11.96 \%$ and the last group progenies derived from (Arbiquine $\mathrm{x}$ Toffahi) clear that oil content was ranged between 17.36 to $18.26 \%$.

e- Oil percent in dry weight.

Since fresh weight is influenced by several factors such as a tree crop and climatic conditions, oil content on a fresh weight cannot be taken into consideration in a comparative quality. This is a reason for using oil content per olive as a fixed criterion, disregarding weight.

Data presented in Fig., 22 clearly indicate that oil content in dry weight was ranging from 51.49 to $53.73 \%$ in progenies derived from (Leccio $\mathrm{x}$ Toffahi), but more than cv. Toffahi. On the other side, progenies derived from (Coratina $\mathrm{x}$ Toffahi) showed that the oil content was ranging from 52.22 to $54.16 \%$, as well as (Toffahi $\mathrm{x}$ Arbiquine) clear that the oil content was ranged from 39.57 to 40.22 and the last group progenies derived from (Arbiquine $x$ Toffahi) showed that oil content scored between 49.17 to $54.56 \%$ and gave the highest oil percent in dry weight and more than cv. Toffahi.

Differences in growth characteristics among olive selections are in close conformity with the 
findings previously reported by many researchers (Saad El-Din et al. 2009, Esmaeili, et al., 2012, Hechmi et al., 2012 and Medina et al., 2012). 5- \% Rooting ability.
Rooting ability of the semi hardwood cutting is illustrated in Fig., 23. It is varied from 15.33 to 19.67 $\%$ (very low). All the progenies were classified as poor rootability progenies.

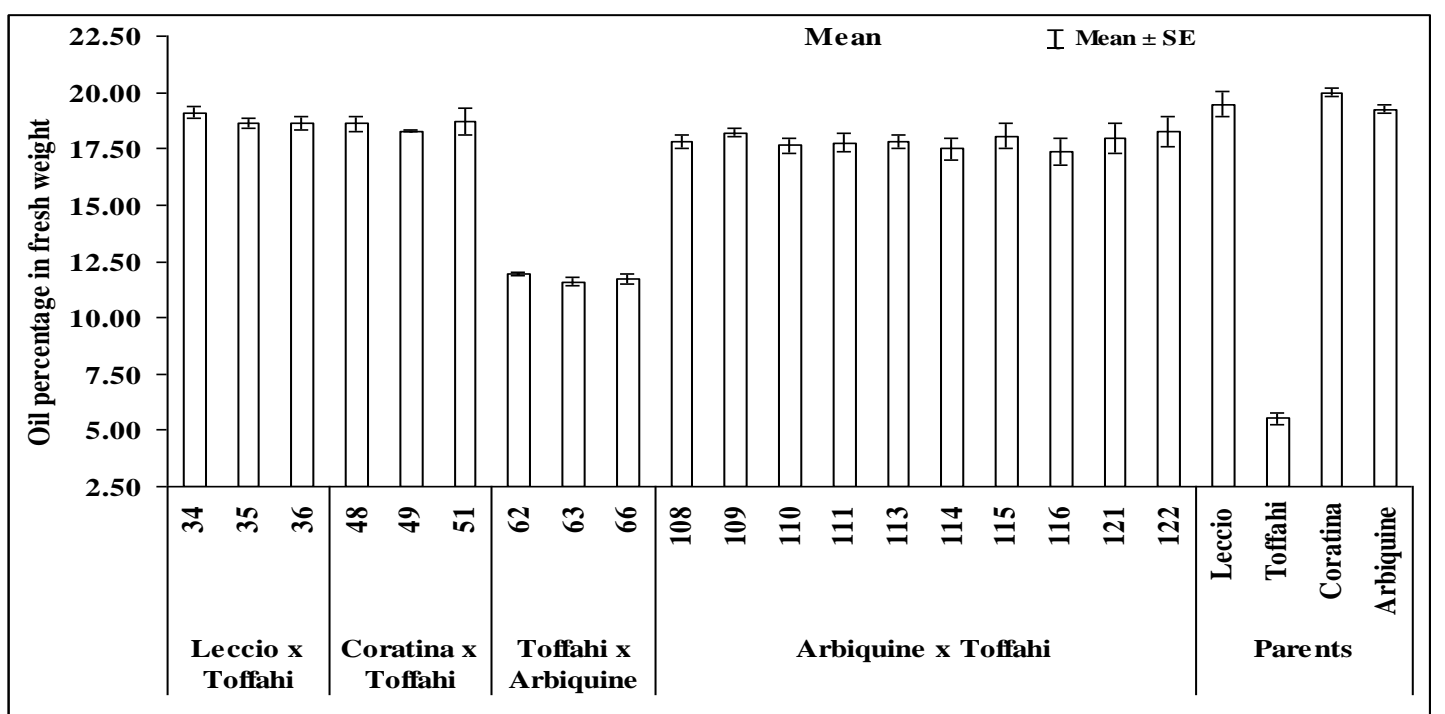

Fig. 21. Mean and standard error during three seasons for oil percentage in fresh weight of the olive progenies.

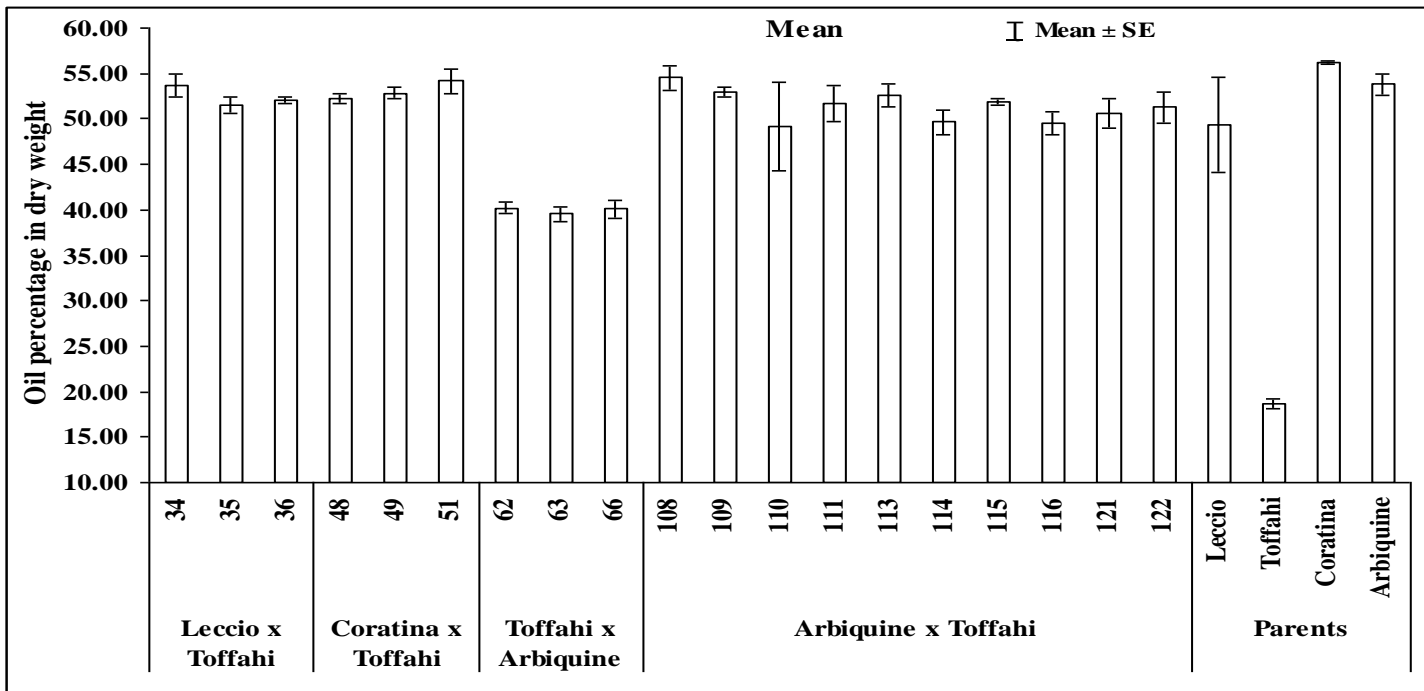

Fig., 22. Mean and standard error during three seasons for oil percentage in dry weight of the olive progenies. 


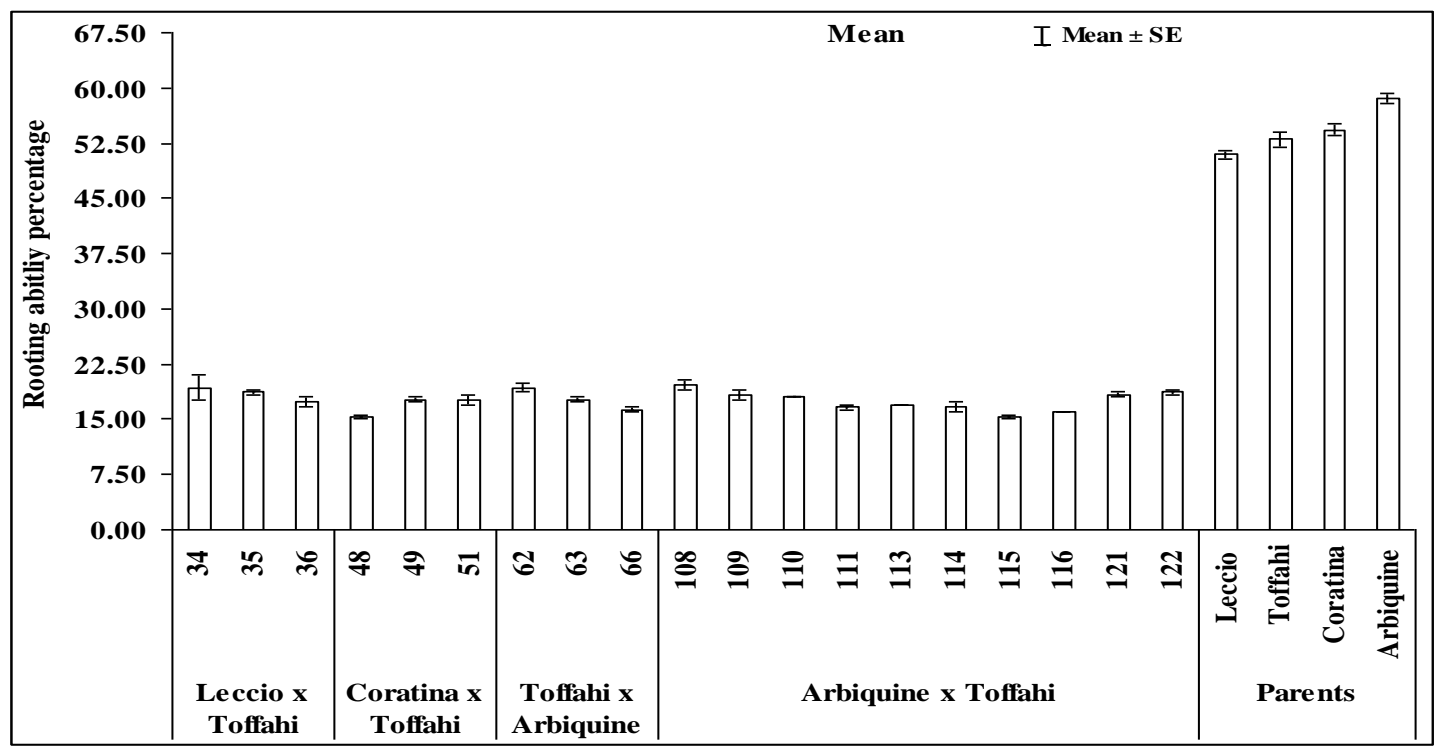

Fig., 23. Mean and standard error during three seasons for rooting ability percentage of the olive progenies. Summary of best characteristics:

\begin{tabular}{|c|c|c|c|c|c|}
\hline \multirow{2}{*}{ Progenies No } & \multicolumn{5}{|c|}{ Characteristics } \\
\cline { 2 - 6 } & Productivity & $\begin{array}{c}\text { Constant } \\
\text { productivity }\end{array}$ & Fruit weight & Flesh/ seed & $\begin{array}{c}\text { Oil content in } \\
\text { dry weight }\end{array}$ \\
\hline 34 & 27.00 & Constant & Very high & Medium & High \\
\hline 35 & 28.40 & Constant & Very high & Medium & High \\
\hline 36 & 26.80 & Constant & Very high & High & High \\
\hline 48 & 27.60 & Alternate & Medium & Medium & High \\
\hline 49 & 28.00 & Constant & High & Medium & High \\
\hline 51 & 28.60 & Constant & Medium & High & High \\
\hline 62 & 23.60 & Alternate & High & Medium & Medium \\
\hline 63 & 25.80 & Constant & Medium & High & Low \\
\hline 66 & 23.40 & Alternate & Medium & Medium & Medium \\
\hline 108 & 26.60 & Constant & High & Low & High \\
\hline 109 & 26.00 & Constant & High & Medium & High \\
\hline 110 & 26.80 & Constant & High & Medium & Medium \\
\hline 111 & 27.40 & Constant & High & Medium & High \\
\hline 113 & 25.40 & Constant & High & Medium & High \\
\hline 114 & 23.60 & Alternate & Medium & Low & Medium \\
\hline 115 & 24.00 & Alternate & Medium & Medium & High \\
\hline 116 & 20.80 & Alternate & Medium & Low & Medium \\
\hline 121 & 23.60 & Alternate & High & Medium & High \\
\hline 122 & 27.60 & Constant & High & Low & High \\
\hline Leccio & 21.50 & Alternate & Medium & Low & Medium \\
\hline Coffahi & 22.90 & Alternate & Very high & Medium & Very low \\
\hline Arbiquine & 23.90 & Alternate & Medium & Medium & High \\
\hline & 32.40 & Alternate & Low & Low & High \\
\hline
\end{tabular}

Thereupon, the preferable progenies are No. 51, 62 and 63 for table olive; whereas progenies No. 36, 49 and 109 for oil. Besides, No. 34, 35, 108, 110 and 111 for dual purpose.

All the best selections under study should be propagated and planted in three different Egyptian environments and data on the vegetative, productive and fruit characteristics (both analytical and technological parameters) must be collected. Finally, new cultivars will be released.

\section{References}

Alfei, B.; Paoletti, A.; Rosatai, Santineli A. and Panellig, A. (2008). Agronomic and qualitative evaluation of olive genotypes selected in central Italy. Adv. Hort. Sci., 22 (2): 136-144. 
Arsel.H. and Cirik N., (1994). General overview of olive breeding in Turkey, Olivae, 52:25-27.

Ayton, J; Mailer, R. J. and Robards, K. (2001). Changes in oil content and composition of developing olives in a selection of Australian cultivars. Australian Journal of Experimental Agricultural. 41: 815-821.

Barranco, D; Cimato, A; Fiorino, P., Rallo. L; Touzani, A; Castaneda, C.; Serafini, F. and Trujillo Nvas, I. (2000). World Catalogue of Olive Varieties. page 15-22, publisher Olive Oil Council.

Bartolini, S.; Andreini, L.; Guerriero R. and Gentili, M. (2006). Improvement of the quality of table olive in Tuscany through crossbreeding and selection: preliminary results of leccino $x$ Kkonservolia hybrids. Olive bioteq. Second International seminar "Biotechnology and quality of olive tree products around the Mediterranean Basin Proceeding Vol.1:143146.

Bellini., E. (1992). Behavior of some genetically characters in olive seedlings obtained by crossbreeding. Acta Horticultural 317: 197-208.

Bellini, E.; Parlati M. V. and Pandolei, S. (1990). Response of crossed olive trees to seedling rooting. Atti XIII International Horticultural Congress Firenze, 26 ago- 1set. 3054 (Abstract).

Bellini, E.; Giordani, E. and Rosati, A. (2008). Genetic improvement of olive from clonal selection to cross-breading programs. Adv. Hort. Sci., 22 (2): 73-86 .

Bellini E., Giordani, E., Parlati, M.V. and Pandofi, S. (2000). Three new olive cultivars obtained by cross- breeding. Acta Horticulturae, 586:221-223.

Bellini E., Giordani, E., Parlati, M.V. and Pandofi, S. (2002). Olive genetic improvement: thirty years of research. Acta Horticulturae, 586:105-108

Biton, I. Shevtsov, S. Ostersetzer, O. Mani, Y. Lavee, S. Avidan, B. and Ben-Ari, G. (2012). Genetic relationships and hybrid vigour in olive (Olea europaea L.) by microsatellites. Plant Breeding; 2012. 131(6):767-774. many ref.

Corderio, A., (1997). Selection de cultivars tolerates. Tesis Doctoral. Universidad de Cordoba.

Cresti, M.; Linskens, U.; Mulcahy, F.; Muleahy, D.L.; Bush, S.; Distilio, J.; XU, M. Y.; Viguani, R. and Cimalo, A. (1997) Preliminary communication about the identification of DNA in leaves and olive of (Olea europaea L.) Adv. Hort. Sci., 10:105-107.

Damijela Poljuha, Barbara Soladonja, Karolin Brkic Bubola and Maria Radulovic (2008). A multidisciplinary Approach to the characterization of Autochthonous Austrian olive (Olea europaea) varieties. Food. Technol. Biotechnol. 46 (4): 346-357
Del Rio, C. and Caballero, J. M. (1994). Preliminary agronomical characterization of 131 cultivars introduced in olive germplasm bank of Cordoba in March 1987. Acta Horticulturae 356:110-115.

Esmaeili, A. Shaykhmoradi, F. and Naseri, R. (2012). Comparison of oil content and fatty acid composition of native olive genotypes in different region of Liam. International Journal of Agriculture and Crop Sciences (IJACS); 4(8):434-438.

Ferri, A.; Padula. G.; Giordani; F. and Billini, F. (2006). First observations on floral biology of advanced selections of olive obtained by crossing. Proceedings of the Second International Seminar Olivebioteq 2006. "Biotechnology and quality of olive tree produces around the Mediterranean basin". vol.1: 127-130

Fontanazza Bartolozzi, G. and Vergatig, F. (1998) Fs-17- Riv. Fruit., 5:61.

Hechmi, M. Raoudha, M. K. and Linda, B. Y. (2012). Distribution of some phenotypical characters within an olive population in Djebel Ouslet. American Journal of Plant Physiology; 7(3):104-119.

Laaribi-Ibtissem, Mouna M. A. and Messaoud M. (2013). Morphometric variability induced by cross breeding of 'chemlali sfax' under different pollination treatments: self-, free- and cross-pollination. J. Nat. Prod. Plant Resour., 2013, 3 (3):20-28.

Laaribi, I., Mezghani, A. M. and Messaoud, M. (2014). Phenotypic diversity of some olive tree progenies issued from a Tunisian breeding program. European Sci. Jour. Feb. 2014 Edition Vol.10, No.6 ISSN: 1857 - 7881.

Lavee, S. (1990). Aims, methods and advances in breeding of new olive (Olea europaea L.) cultivars. Acta Horticulturae 286, 23-36.

Lavee S.; Avidn, B. and Meni; Y. (2003). "Askal" a new high performing oil variety for intensive and super- intensive olive orchards Olivae, 97: 53-59.

Lavee, S.; Haskal; A. and Vodner; M. (1986). "Barnea" a new olive cultivar for oil extraction resistant to Spilocaea Oleagina. Acta Horticulturae 474: 125-128.

Lavee, S.; N. Avidan, A. Haskal and A. Ogrodovich (1996). Juvenility period reduction in olive seedlings-a tool for enhancement of breeding. Olivae 60: $33-41$

Lavee S.; Avidan; B., Meni; Y.; Kaskala and Wodner, M. (2004). Three new varieties of semi-dwarf table olives- Olivae 102: 33-41.

Lavee. S.; Harshemesh, H.; Haskal, A.; Avidan; B.; Grodovich, A.; Avidan N. and Trapero, A. (1999). Maalot a new cultivar for oil extraction resistance to spilocaea oleagina. Acta. Horticulturae, 474: 125- 128.

Leon, L. Rosa, R. de la Barranco, D. and Rallo, L. (2004). Ten years of olive breeding in 
Cordoba (Spain). Acta Horticulturae; 2004. (663(Vol.2)):747-750. 10 ref.

Leon L.; De La Rosa, R.; Barranco, D. and Rallo, L. (2006). Agronomic characterization of 15 selections of the olive cross breeding program of Cordoba, Spain. proceedings of the Second International Seminar olivebioteq. "Biotechnology and quality of olive tree produces around the Mediterranean basin" . vol.1:87-93.

Leon, P. J. Talhaoui, N. Leon, L. Rosa, R. de la Velasco, L. Perez-Vich, B. (2013). Fruit and oil characteristics of advanced selections from an olive breeding program. Acta Horticulturae; 2013. (976):415-419. 15 ref.

Medina, E. Morales-Sillero, A. Ramirez, E. M. Rallo, P. Brenes, M. Romero, C. (2012). New genotypes of table olives: profile of bioactive compounds. International Journal of Food Science \& Technology; 47(11):23342341.

Pannelli, G.; Rosati, A.; Pandolfi., S, Padula, G., Mennone, C.; Giordani, E. and Bellini, E. (2006). Field evaluation of olive selections derived from a breeding program. olivebioleq. Proceeding of the Second International Seminar "Biotechnology and quality of olive tree products around the Mediterranean Basin. Vol. 1:.95-102.
Pritsa, T. S.; Voyiatzis, D.G.; Voyiatzis, C.J. and Sotiriou, M.S. (2003). Evaluation of vegetative growth traits and their relation to time to first flowering of olive seedlings. Australian Journal of Agriculture Research 54, 371-376.

Rallo, (1995). Selection and breeding of olive in Spain. Olivae, 59: 46-53.

Saad El-Din, Ikram, E.G. Mikhail and I.M.S. Osman (2009). Evaluation of some olive hyprids derived from a breeding program. J. Agric., Sci. Mansoura Univ., 34(7):8111-8128.

Sanchez de Medina, V. Calderon-Santiago, $M$. El-Riachy, M. Priego-Capote, F. and Luque de Castro, M. D. (2014). High-resolution mass spectrometry to evaluate the influence of crossbreeding segregating populations on the phenolic profile of virgin olive oils. Journal of the Science of Food and Agriculture; 2014. 94(15):3100-3109. 27 ref.

Santos-Antunes, A F.; Mohedo, A.; Trujillo, I. and Rallo, L. (1999). Influence of the genitors on the flowering of olive seedlings under forced growth. Acta Horticulturae, 474 :103-105.

Sonnoli, L.; Sonnoli A.; Sonnoli, S. and Sonnoli, E. (2003). CSS Diana-Plant Varieties Journal, 16 (2): 61.

Trigui, A. (1996). Improving the quantity and quality of olive production in Tunisia. Olivae. 61: 34-40.

$$
\begin{aligned}
& \text { تقييم بعض هجن الزيتون الناتجة من برنامج التحسين الوراثى } \\
& \text { إبراهيم محمد سيد عثمان } \\
& \text { قسم بحوث الزيتون وفاكهة المناطق شبه الجافة - معهد بحوث البساتين - مركز البحوث الزراعية } \\
& \text { الملخص العربى } \\
& \text { فى مصر قد تم تأسبس برنامج التحسين الوراثى } 1994 \text { بإجراء عمليات التهجين بين الأصناف المحلية والأجنبية من أجل الحصول } \\
& \text { على أصناف مائدة أو زيت أو ثثائية الغرض عن طريق الانتخاب والتقييم. وللعمل المستقبلى فقد صمم لأقلمة الأصناف الواعدة لكى تلائم الأجواء } \\
& \text { المناخية المختلفة. } \\
& \text { وخـلاد ثـلاث سـوات تم تقييم هذه الهجن الناتجـة من التهجين من (ليسيو × تفاحى)، (كوراتينـا × تفاحى)، (تفاحى × أربكوين) و } \\
& \text { (أربكوين × تفاحى)، وتم دراسـة هذه السـلالات وتقييم صفاتها (طول الفرع - سمك الفرع وعدد العقد على الأفرع) الأوراق (متوسط عدد الأوراق }
\end{aligned}
$$

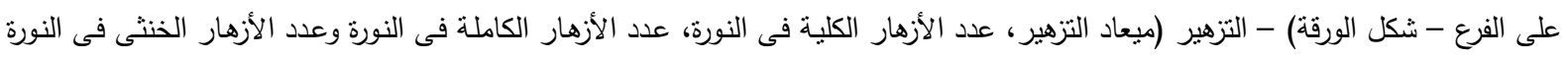

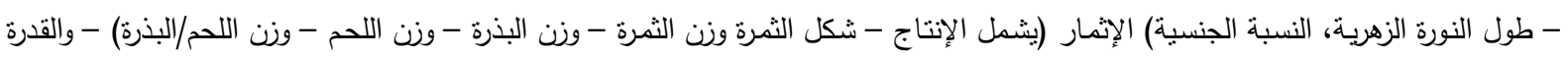

$$
\begin{aligned}
& \text { على التجذير . } \\
& \text { وتتشير النتائج المتحصل عليها أنه أمكن التوصل إلى أحسن الهجن لإنتاج زيتون مائدة هى رقم 51، } 62 \text { و } 63 \text { ولإنتاج الزيت رقم } \\
& \text { 36، 49، } 109 \text { و } 121 \text { ولإنتاج ثنائي الغرض 34، 35، 35، 108، } 110 \text { و } 111 . \\
& \text { وعليه فإنه يجب إجراء تكاثر خضري لهذه الهجن فى مناطق مختلفة الجغرافية، وتزرع شتلات هذه الهجن فى ثناثة أماكن مختلفة وذلك }
\end{aligned}
$$

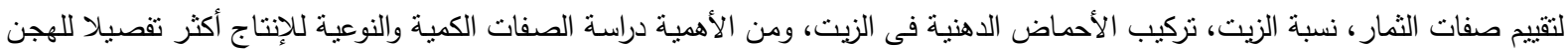

$$
\begin{aligned}
& \text { الأكثر تميزا. }
\end{aligned}
$$

